\title{
DIODORUS CRONUS AND HELLENISTIC PHILOSOPHY
}

\section{§1. Introduction. 1}

During the last four decades historians of ancient logic have become increasingly aware of the importance of Diodorus Cronus and his pupil Philo as pioneers of the propositional logic which came to flourish in the Stoa. ${ }^{2}$ Their direct influence has so far been recognised in two main areas of Hellenistic controversy - the validity-criteria for conditional propositions, and the definition of the modal terms 'possible' and 'necessary'. But some broader questions have not been satisfactorily answered. What were Diodorus' own philosophical allegiances and antecedents? What is his place in the history of Greek philosophy? How far-reaching was his influence on the post-Aristotelian philosophers?

There was little chance of tackling these questions confidently until 1972, when Klaus Döring published for the first time the collected fragments of Diodorus, in his important volume Die Megariker. Meagre though they are, these fragments confirm my suspicion that Diodorus' philosophical background has not been fully explored, and also that his influence on the three emerging Hellenistic schools - the Stoics, Epicureans, and Sceptics - was far wider than has hitherto been recognised. There has been much discussion as to which earlier philosophers played the most decisive part in shaping Hellenistic philosophy, and the respective claims of the Platonists and of Aristotle have never lacked expert advocacy. In all this, the claims of so obscure a figure as Diodorus have been underrated.

\section{§2. Diodorus' school.}

Although Diodorus was not active before the last part of the fourth century, any discussion of his philosophical allegiances must begin with Euclides of Megara at the beginning of the century. Euclides evolved a philosophy out of certain key ideas borrowed from Parmenides and Socrates. Eleatic monism, in partnership with Socratic ethics, provided him with the slogan 'The Good is one thing, called by many names'. In time a school named the Megarian ${ }^{3}$ was fathered on him, true to his main teachings but updated with an injection of Cynic morality. After a quiet period under the leadership of one Ichthyas, ${ }^{4}$ it regained prominence in the late fourth and early third centuries under one of the most celebrated philosophers of the age, Stilpo of Megara.

That, very briefly, is the Megarian school, and it is universally held that 
Diodorus was one of its members. But he was not. He belonged to a rival group which in his day called itself the Dialectical school. That this palpable fact has been overlooked for so $\operatorname{long}^{5}$ seems due to a confusion between a diadoche, or philosophical succession, and a hairesis, or school. A hairesis is normally a unified sect recognised as such by its members, whereas a diadoche is a neat family tree of philosophers constructed by Hellenistic biographers. Diogenes Laertius starts his section on Euclides by telling us that Euclides' successors ${ }^{6}$ were called Megarikoi, then Eristikoi, and later Dialektikoi. It has always been assumed that these were three successive labels applied to a single school, ${ }^{7}$ and hence that anyone called a Dialektikos was really a Megarian philosopher masquerading under another name. But it is also possible that what Diogenes has described here is a diadoche rather than a single school; and the possibility is strengthened when we note that the only named source in this section is the Diadochai of Alexander Polyhistor. Might not the correct interpretation be that these three labels - Megarikoi, Eristikoi, and Dialektikoi were titles applied at different times to various distinct groups of philosophers conventionally regarded as Euclides' heirs? The possibility becomes a certainty when we look at one unimpeachable item of evidence testifying that the Dialecticians and the Megarians were entirely distinct schools at the end of the fourth century. Diogenes preserves verbatim a quotation from Philippus the Megarian philosopher, who illustrated his master Stilpo's success in recruiting pupils for the Megarians from other schools with a list of conversions culminating as follows:

'From the Dialecticians he won over as devoted disciples not only

Paeonius the former follower of Aristides but also Diphilus of the Bosporus, follower of Euphantus, and Myrmex son [or 'follower'?] of Exaenetus, both of whom had come to refute him.'8

This achievement would scarcely be to Stilpo's credit if the Dialecticians and the Megarians were one and the same school. If, then, the Dialecticians were a distinct and rival group, what do we know of them? The question may seem to be complicated by two facts: that for Plato and Aristotle 'dialektikos' designates not a member of a specific school but a practitioner of a certain philosophical method; and that by the time of Chrysippus, in the late third century, it is the standard term for 'logician'. But fortunately there is evidence that in the intervening period 'Dialektikoi' was in use as the title of a school. For a school of this name was attacked by Epicurus, ${ }^{9}$ by his pupil Metrodorus, ${ }^{10}$ and by the Stoic Ariston of Chios. ${ }^{11}$ Its best known members were Diodorus Cronus and Philo. Neither of these has any known connexion with Megara or the Megarian school, and both are regularly labelled 'dialektikos'. 2 The 
school itself was perhaps somewhat makeshift in character. It barely outlasted two generations, and although Diogenes Laertius recognises it as a hairesis and places it alongside the Megarian school, he also quotes the historian of philosophy Hippobotus as denying it this status. ${ }^{13}$ Hippobotus' denial is not damning: his list of nine haireseis is restricted to the most strongly ethical schools, and his caution in these matters is shown further by his denial that there was even a Cynic hairesis. But it may well be that the Dialectical school was bound together by a community of interests rather than of beliefs, and that it lacked the clear doctrinal stamp that characterised most contemporary sects.

The Dialectical school was first given its name by one of its members, Dionysius of Chalcedon, an approximate contemporary of Diodorus. ${ }^{1} 4$ Its philosophical method was that which takes its starting point in commonly held views and proceeds by means of question and answer. ${ }^{15}$ This is dialektik $\bar{e}$ in the sense recognised by Aristotle, and the school's title was thus readily understood. But for us it is quite uninformative about the school's actual philosophical preoccupations. Here, by good luck, another scrap of evidence comes to the rescue. The Dialectical school, we are told, used to name as its founder a certain Clinomachus of Thurii, a pupil of Euclides, who can thus be dated to the early or mid fourth century, one or more generations before Diodorus. ${ }^{16}$ Since the school was first given its name by a contemporary of Diodorus, we can rule out the possibility that Clinomachus 'founded' it in any strict sense. Either he formed a circle which came to be seen as the forerunner of the Dialectical school, or more likely, he was chosen with hindsight as its figurehead because he was recognised as a forerunner of its most central ideas, and because it wished to establish the priority of its own tradition over the competing logical systems of the Peripatos and Academy.

What, then, do we know of Clinomachus' work? Precisely one fact, but of the utmost significance - that he was 'the first to write about

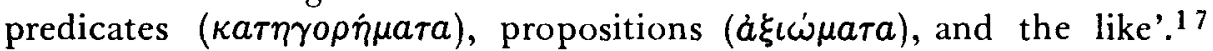
Does this sweeping claim make Clinomachus out to be the founder of both branches of logic that came to flourish side by side in the Hellenistic period - the predicative logic of the Peripatetic school and the propositional logic of the Stoa? ${ }^{18}$ If so, it cannot have been principally for any contribution to predicative logic that the Dialectical school looked back to Clinomachus as its founder. The fragments of Diodorus and Philo suggest only lukewarm interest in this area, ${ }^{19}$ and there can be little doubt that it was more for his pionecring study of propositional logic, the logic of axiomata, that they revered Clinomachus. This was the area in which Diodorus and Philo made their mark and left a legacy of incalculable importance for the logicians of the Stoa. 
Now for a thumbnail sketch of Euclides' diadoche. After his death, c.365 B.C., ${ }^{20}$ three separate traditions emerged - the same three in fact which Diogenes Laertius lists as Megarikoi, Eristikoi, and Dialektikoi, although it would be rash to assume that these were all official or contemporary titles. The Megarikoi are those Cynically-inclined moral philosophers best represented by Stilpo. The Eristikoi (though if such a group ever officially existed they can hardly have used this unflattering name for themselves) are those who built their philosophical method around the use of logical puzzles, and of these the best known is Eubulides, ${ }^{21}$ a contemporary and opponent of Aristotle. Eubulides is of importance to this study, because his pupil Apollonius was the teacher of Diodorus Cronus, who inherited and built on his fascination with logical puzzles. Another who is sometimes called 'eristikos' is Alexinus, a rough contemporary of Diodorus, well known as a sophistical debater; but here we are on very uncertain ground. ${ }^{22}$ The Dialektikoi, finally, are those who took up the constructive study of logic, flourishing above all in the early Hellenistic period but tracing their ideas back to Euclides' pupil Clinomachus. They were brought together by a common interest in propositional logic, however diverse their other ideas and methods may have been. And this, if correct, explains the brevity of their separate existence: within a few decades propositional logic had found itself a home in the Stoa, thus depriving the Dialectical school of its raison d'être. I have collected the names of fourteen Dialektikoi, and a variety of references to the school, and most if not all can be dated to the period $320-250.23$

The recognition of these distinctions should help eliminate the common error of imputing the doctrines of Stilpo to Diodorus or vice versa. ${ }^{24}$ The precise nature of their philosophical divergences and agreements would be a valuable topic of research, but cannot detain us here. ${ }^{25}$

So much for Diodorus' formal standing among the Greek philosophical schools. It may be helpful at this stage to offer a brief synopsis of his own philosophical outlook. At first sight it appears that he took seriously his school's status as heir to the philosophy of Parmenides and Zeno, for many of his recorded arguments are linked by the same formal goal as that commonly attributed to Zeno - to corroborate Parmenides' doctrines by showing that the common-sense opinions denied by him are no less absurd. Hence Diodorus, in addition to an argument against perishing, and probably another against becoming, had his own four proofs of the impossibility of motion, in direct emulation of Zeno. But the superficiality of this Eleaticism is apparent in his concession that a thing can be said to have moved. In this connexion he also evolved a theory of amere, partless constituents of matter, although there is no sign that he pursued any broader cosmological interests. In all this Aristotle seems to 
have been the main source of his ideas, and his underlying purpose was apparently not to deny outright the existence of a world of change and plurality, but rather to highlight its paradoxes and to create new ways of thinking about it. To the same end he brought into his repertoire a number of logical puzzles which had been devised by his forerunner Eubulides. Some of these came to be as closely associated with Diodorus as with Eubulides, and for this reason I shall assume, wherever one of Eubulides' riddles has passed to the Hellenistic philosophers, that Diodorus is the main vehicle of transmission, even though other members of his school are more than likely to have played a part. In instances like this Diodorus' importance lies not in originality (which is in any case hard to establish) but in his ability to impress ideas upon his contemporaries. His sophistical leanings, his flamboyancy, and his love of showmanship are his heritage from Eubulides, and must never be lost sight of if we are to understand the extent of his impact. On the other hand, it is fairly clear that he taught his pupils not merely to propound these puzzles but also to solve them. ${ }^{26}$ He was, I would say, a specialist in arguments rather than in doctrines, and the Eleatic tendency of his work reflects less a doctrinal attachment to Parmenides and Zeno than a recognition of them as the founder-figures of dialectic. Hence his primary importance is for his pioneering work as a constructive logician. He and his colleagues concentrated on the logic of propositions, and this led them off in a rather different direction from the school of Aristotle, whose logic dealt chiefly with the relations that obtain between individual terms. The best known debate of the time was that as to how and when one proposition can be said to follow from another; but it seems likely that they also worked on inference schemata of the kind later systematised by the Stoics. Another hotly debated topic was the definition of the modal terms 'possible' and 'necessary', and Diodorus, by means of his famous Master Argument, was able to formulate and defend definitions of them which avoided the usual danger of circularity.

\section{§3. Diodorus'dates, life, and contacts.}

I have spoken vaguely of Diodorus' period of activity as belonging to the end of the fourth century. This was a period of rapid change in Greek philosophy, and it is important to pin down his dates and movements as accurately as possible if we are to make any headway in investigating his influence on his contemporaries. He was born at Iasos, an Ionian town in Caria, and studied dialectic with a pupil of Eubulides named Apollonius. Apollonius came from Cyrene, and was known as ó Koóvos, which meant Old Codger. It was Diodorus' misfortune to inherit this unprepossessing nickname. ${ }^{27}$ The fact that Diodorus studied with one of the less 
distinguished dialecticians of the age suggests perhaps that he was still at this time living in Asia Minor, and had not yet made the inevitable move to Athens, the hub of the philosophical world. When we next hear of him he is already set up in Athens as a teacher of dialectic, attracting to his lectures such future Stoics as Zeno of Citium and Zeno of Sidon, as well as his own subsequent colleague Philo. ${ }^{28}$ Zeno of Citium probably did not arrive in Athens until $312 / 1,29$ and even then his first teacher was the Cynic Crates. Thus his studies with Diodorus can be placed with reasonable confidence in the last decade of the fourth century. This also becomes our earliest date for Diodorus' teaching career, although there is no reason why it should not have begun many year earlier.

There are still signs of Diodorus' influence at Athens during the 290's. Epicurus, in a book securely dated to $296 / 5$, twice attacks unnamed opponents for doctrines and arguments which are plainly those of Diodorus. ${ }^{30}$ And Arcesilaus, who did not arrive in Athens before the mid 290's, was believed by a contemporary to have come under the influence of Diodorus (see below). But after this the main scene of Diodorus' activities seems to shift to Alexandria, where the patronage of Ptolemy Soter was beginning to attract an influx of philosophers and other intellectuals. One anecdote makes Diodorus a friend of the great physician Herophilus, ${ }^{31}$ who himself lived in Alexandria. Diodorus, the story goes, one day went to Herophilus with a dislocated shoulder, and Herophilus borrowed one of his own arguments against motion to prove to him that he could not have dislocated it. The story is a typical Hellenistic fabrication, ${ }^{32}$ but it at least provides evidence that the friendship was geographically and chronologically possible. Herophilus was probably born about 320 B.C., ${ }^{3}$ and this makes it hard to date the alleged incident earlier than 290. Confirmation comes from an epigram of Callimachus: ${ }^{34}$

"Momus himself used to write on the walls, "Cronus is wise". Look, even the ravens on the rooftops are cawing "What follows from what?"

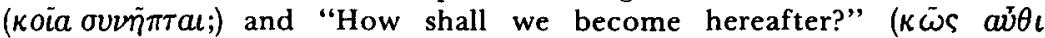

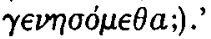

The pairing of the two couplets is conjectural, and the precise meaning of the epigram is debatable, ${ }^{35}$ but it is at least worth noticing that the ravens use the Ionic forms koia and $\kappa \hat{\omega} \varsigma$, which no doubt imitate not only their cawing but also Diodorus' Ionian accent. This is clear evidence that Diodorus was still a familiar figure on the Alexandrian scene when Callimachus first arrived there from Cyrene, probably in the period 290-85.36

These pointers suggest that Diodorus is unlikely to have died before 
285. The story of his death comes in another anecdote. He was in Alexandria, where both he and Stilpo happened to be guests at a banquet given by Ptolemy Soter. ${ }^{37}$ Stilpo presented Diodorus with a set of logical puzzles, which he could not immediately solve. Ptolemy made things worse by scolding Diodorus and calling him by his nickname Cronus. Diodorus left the court, wrote out a solution to the problem, then died in misery. The joke of Diodorus, who made his living from logical puzzles, eventually being killed by a logical puzzle once again makes the details of the story suspect. But this need cast no doubt on the reported historical setting of his death. One might usefully compare the anecdote often told in histories of mathematics about the humiliation of Diderot at the court of Catherine the Great in 1774. The current version is that Diderot was laughed out of court for his inability to answer an absurd algebraic proof of the existence of God propounded by the Swiss mathematician Euler. Comparison with the sole original source shows that the details have been altered to make the atheist Diderot come off the worse. ${ }^{38}$ On the other hand, as often happens in such cases of distortion, the historical facts of the encounter, in particular the date and setting, have been accurately preserved. So too with the Diodorus story, the obviously unreliable details should not lessen its value as evidence that Diodorus died in Alexandria during the reign of Ptolemy Soter. So Diodorus' death must be placed after 285 (as already established) but before Ptolemy's own in 283/2. For convenience I shall say that $\mathbf{2 8 4}$ was the approximate date of his death.

We do not know at what age he died, but if fifty years is taken as a reasonable upper limit for a philosopher's period of mature activity we can regard 334 as the earliest possible date at which his influence might have been felt. Those who believe that Diodorus influenced Aristotle, who died in 322, can now at best date the period of influence to the last dozen years of Aristotle's life - and even that is against the odds. It has been important to establish this chronology, because most writers on Diodorus still accept 307 as the date of his death, ${ }^{39}$ and this, if correct, would allow plenty of overlap with Aristotle. A more correct picture is as follows. Diodorus lived a full generation after Aristotle and absorbed many ideas from his reading of Aristotle's works. He was active in Athens at precisely the time when Zeno, Arcesilaus and Epicurus, the founders of the three Hellenistic schools, were arriving there and learning the ropes. And, as I hope to show, he exercised a major formative influence on the new style of philosophy.

The next question is precisely how Diodorus achieved his impact. There is no evidence that he ever published his ideas in written form, and certainly when Epicurus denounces them in the fragments of his On 
nature he makes it clear that they were known to him not through books but through personal contact. Oral debate is anyhow the natural medium of dialectic. If any of Diodorus' ideas were written down, it is not unlikely that Philo played Plato to his Socrates. For example, we know that Diodorus' five exemplary daughters, all of whom became Dialecticians, were featured in Philo's Menexenus, ${ }^{40}$ and it would not be surprising if Diodorus himself was portrayed there too. ${ }^{4}$ His preference for oral presentation would explain why his logic came to be so much better known than that of the Peripatetics - it was necessarily kept simple. The use of written formal logic always leads to greater complexity. Diodorus' Master Argument was said to be a favourite subject of conversation at dinner ${ }^{4} 2$ (would any of the versions of it reconstructed by modern logicians be such an instant passport to social success?), and in the image created by Callimachus even Diodorus' question 'Which conditionals are valid?' was being shouted by ravens from the rooftops in Alexandria.

Let us now consider his influence on the Stoa. Zeno, its founder, studied dialectic under him, and although he wrote little of importance on logic himself he used to teach his pupils to solve logical puzzles of the kind bequeathed by Diodorus. ${ }^{4} 3$ In this way the logic of propositions was developed simultaneously by early Stoics like Cleanthes and by Dialecticians such as Diodorus, Philo, and Panthoides, and the logics of the two schools became closely linked. The general nature of this development has been so well sketched by Frede in his recent book on Stoic logic ${ }^{4}$ that I feel absolved from going over all the same ground here. There are just two scores on which Frede is led to underestimate the degree of influence. At one point ${ }^{4}$ he uses Ch:ysippus' reported disparaging remarks about the sophisms of Stilpo and the Megarians as a ground for emphasising his independence of the 'Megarian' tradition: but once we make the correct distinction between Megarians and Dialecticians this will offer no ground for seeing a direct break between Diodorus and Chrysippus. On the contrary, so little did Chysippus scorn the puzzles bequeathed by Diodorus that he wrote more than thirty books on them. Secondly, Frede observes that Cleanthes was at least independent enough of Diodorus to dispute the validity of the Master Argument, and hence did not respect Megarian orthodoxy. ${ }^{46}$ This argument too is disposed of by the correct Megarian-Dialectician distinction: there simply was no orthodoxy in the Dialectical school, and Diodorus' views on modal logic were disputed as hotly by his colleagues Philo and Panthoides as by any opponent.

What is less recognised is Diodorus' influence on the other two main Hellenistic schools. Epicurus arrived in Athens in 307/6, and, as I have 


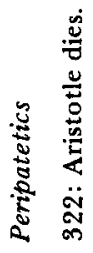
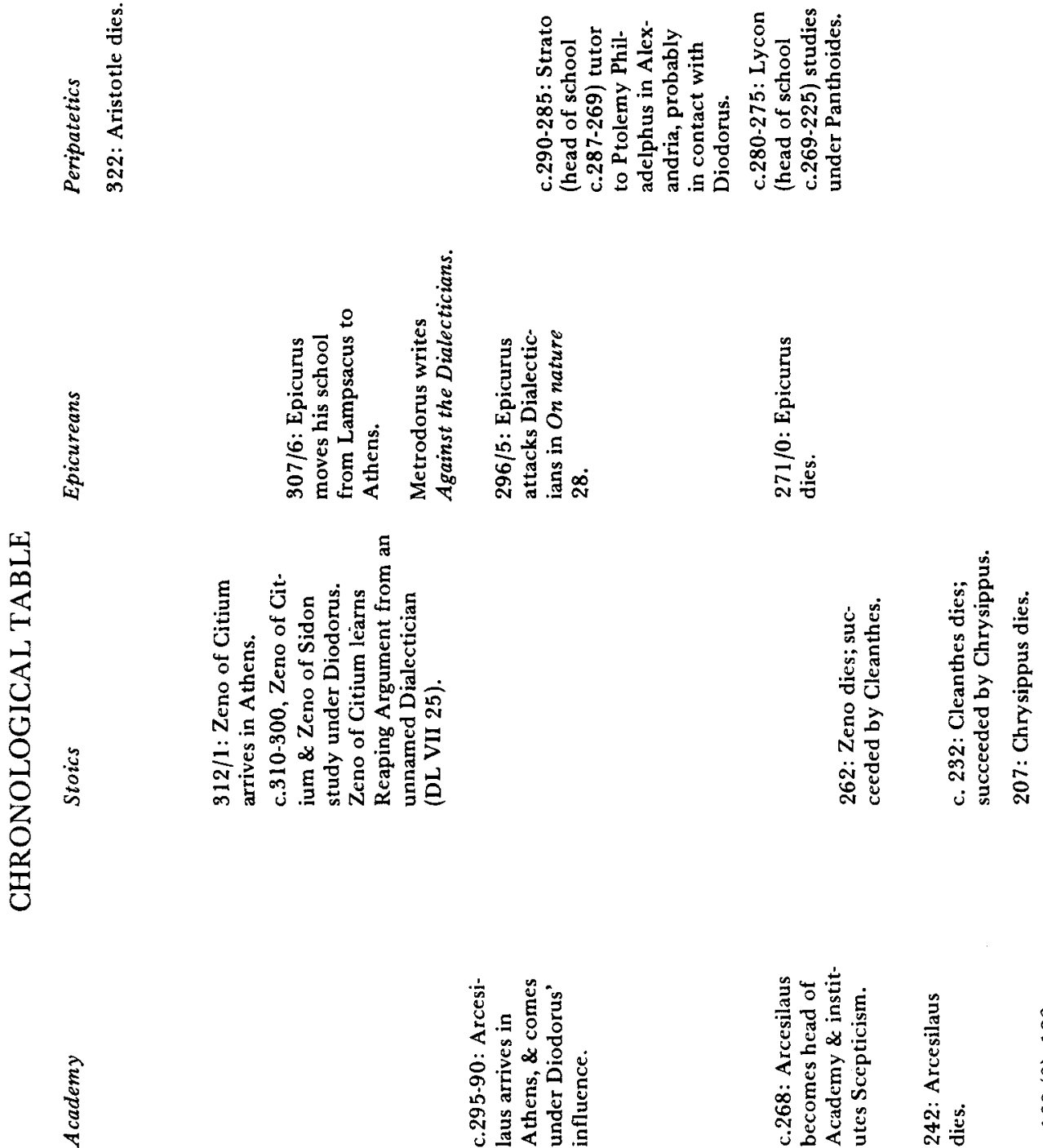

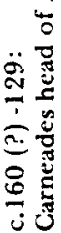
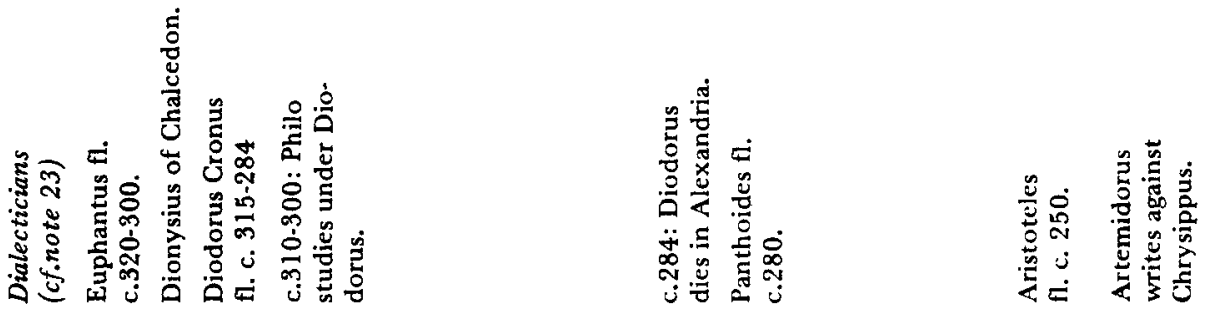
mentioned above, the fragments of a book he wrote eleven years later show unmistakable signs of reaction against Diodorus, or against Dialecticians employing Diodorus' arguments. ${ }^{7}$ Then again Arcesilaus, who achieved the most stunning coup of the era by delivering over to scepticism that pillar of the establishment the Academy, was said to be under the influence of Diodorus. A contemporary Stoic, Ariston of Chios, adapted Homer's line about the Chimaera and described Arcesilaus as

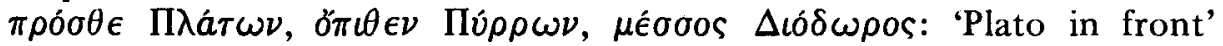
because he was officially a Platonist; 'Pyrrho behind' because Pyrrho was the father of the scepticism which he espoused; and 'Diodorus in the middle' because, so Sextus tells us, he employed the dialectic of Diodorus. 48 We know so little of Arcesilaus' individual arguments that specific Diodorean influence is bound to be hard to detect; but I shall be offering what clues I have been able to muster. The correct picture, I think, is that Diodorus taught both the use of dialectical puzzles and the logic of their solution; and that the former skill became the backbone of scepticism in the Academy, ${ }^{49}$ while the latter contributed to the evolution of Stoic logic.

The channels through which Diodorus' influence was disseminated are best set out in the form of a family tree:-

\section{Epicureans Dialecticians Stoics Academy}

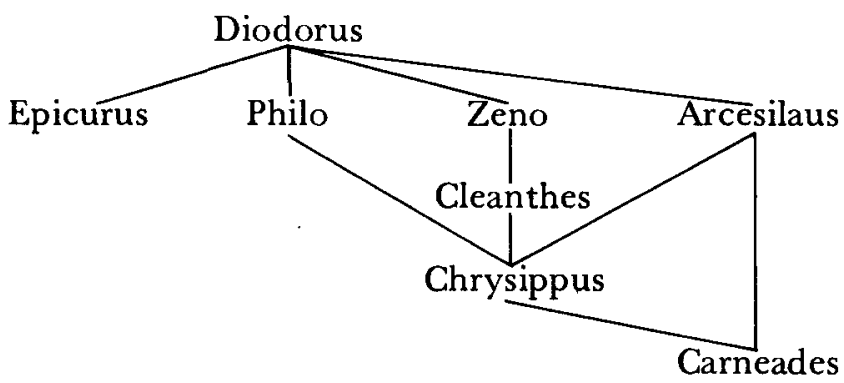

I am aware that both here and in what follows I must of ten appear to be overlooking the contributions of other philosophers to Hellenistic philosophy. The reason is that the claims of Plato and Aristotle in this regard have already been well aired, and one of my aims in putting Diodorus' case is to redress a balance. In this context it would be unwise to pretend objectivity in any comparative assessment of his importance. Instead, I shall simply take Diodorus' arguments one by one and try to illustrate the imprint which they left on subsequent philosophy. 


\section{§4. The motion paradoxes and the theory of minima.}

Diodorus' series of puzzles concerned with motion provides a useful illustration of the strengths and weaknesses of his argumentative methods, of his debts to his predecessors, and of his impact on his contemporaries and successors. The number of these puzzles is not specifically recorded, but Zeller was probably right to distinguish four separate ones among those discussed by Sextus. ${ }^{50}$ This figure has the attraction of highlighting Diodorus' emulation of Zeno of Elea, himself the author of four such puzzles. There are, it is true, signs that Diodorus used the non-existence of void as a premiss for a further argument, after the fashion of Melissus, but this was too well known for him to have claimed it as his own invention. 51

The question 'Does motion exist?' was taken seriously enough by the Sceptics to occupy twenty-eight pages in the Teubner text of Sextus. 52 There are, he observes at the outset, three possible opinions: (a) that motion exists - the view favoured by most ordinary people and philosophers; (b) that motion does not exist - as asserted by Parmenides, Melissus, and Diodorus Cronus, 'unless one should say that according to the latter a thing "has moved" but not that it "is moving" '; and (c) that motion no more exists than does not exist - the correct Sceptic standpoint. A glaring omission among the adherents listed for position (b) is the name of Zeno. Salt is rubbed into the wound when Sextus quotes Zeno's celebrated dichotomy argument but wrongly attributes it to Parmenides and Melissus, and in the ensuing discussion he shows himself quite unaware of Zeno's pioneering contribution to the debate. Instead it is Diodorus who is seen as the dominant figure.

The extraordinary truth is that Diodorus' eminence had all but pushed Zeno into oblivion. Nor is this oblivion much mitigated by the recognition which another Sceptic source, quoted by Diogenes Laertius, ${ }^{53}$ accords to Zeno. According to this, some actually regarded Zeno's denial of motion as making him the founder of Scepticism. But the argument which he goes on to cite from Zeno by way of illustration is one which, far from being genuinely Zenonian, is elsewhere reliably attributed to Diodorus: the moving object moves neither in the place where it is nor in the place where it is not. ${ }^{54}$ Attempts have sometimes been made to vindicate its Zenonian authorship, ${ }^{55}$ wrongly in my view. This disjunctive form of argument against change is highly characteristic of Diodorus, and closely resembles another Eleatically inclined argument used by him to attack the notion of perishing: 'If the wall perishes, either the wall perishes when the stones are in contact and fitted together, or it perishes when they are apart. But neither does the wall perish when they are in contact and fitted 
together, nor does it perish when they are apart from each other. Therefore the wall does not perish. 56

This last paradox attempts to outlaw change by depriving it of a time at which to happen. The motion argument similarly denies a moving object space in which to move. The full version, as recorded by Sextus, is this: 'If something moves, it moves either in the place where it is or in the place where it is not. But it moves neither in the place where it is (for it is at rest in it), nor in the place where it is not (for it is not in it). Therefore it is not the case that something moves. ${ }^{\prime} 7$ Why is the object necessarily at rest in the place where it is? Because, Sextus explains, ${ }^{58}$ it exactly fills it. Any three-dimensional object occupies a space whose boundaries coincide with its own; to expect it to move in that space would be like asking a banana to move about inside its skin. ${ }^{59}$ It was objected, of course, that Diodorus' disjunction misrepresents the true nature of motion: a moving object moves not in a place but from one place to another. However, Diodorus' position was easily defended on this score, as Sextus demonstrates, by a neat switch from spatial to temporal disjunction. If the object passes from its initial position, A, to another position, B, when does it do so? Not while it is still in A, since that is before it has moved; and not when it is no longer in $\mathrm{A}$, since by then it has already passed out of $\mathrm{A}$. Hence there is no time at which it can pass from $A$ to $B .60$

Diodorus' conclusion was not that of Zeno, that motion is an illusion. His goal in adopting Eleatic procedures was apparently not to abolish the sensible world but to find new perspectives for looking at it. In this instance he argues that it can never be correct to say of something 'It is moving', but that, since experience nevertheless tells us that things are in different places at different times, we are permitted to say 'It has moved'. This, if paradoxical, is by no means nonsense. Compare the analysis of motion offered by Russell, who accepted Zeno's argument that nothing moves at an instant and described motion as a series of separate states: 'There is no transition from place to place'; 'Nothing happens when a body moves except that it is in different places at different times.' 61 That Diodorus was equally serious about his own analysis is demonstrated by his strenuous, efforts, recorded by Sextus, to prove that it is logically possible for a statement to be true in the past tense without ever having been true in the present tense. 62

However, the real origin of this analysis of motion seems to lie not in the paradox discussed above but in another, closely allied, paradox, which exploits his doctrine of amere - indivisible or partless magnitudes. In

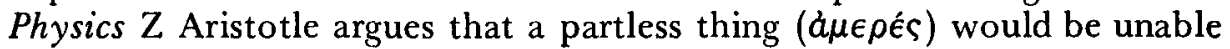
to move. ${ }^{63}$ If it moves into an adjacent space there can be no time at 
which it is half-way, since it has no half, and so it must remain at rest during the whole time that it is moving. Therefore it never 'is moving', but can be said to 'have moved' - a consequence which Aristotle sees as sufficiently absurd to refute the idea of a 'partless' body in motion. But Diodorus was able to take over the argument and to run it in reverse. First he established that partless entities are the basic constituents of matter. He then used the Aristotelian argument to infer from this that nothing is moving' but that things can nevertheless be said to 'have moved'. ${ }^{4}$

This brings me to a digression about Diodorus' influence on Epicurus. Epicurus held that an atom, although not itself a theoretical minimum, consisted of a finite number of theoretical minima. Some important work by Furley ${ }^{65}$ has shown how this theory was evolved to circumvent arguments of Aristotle's in Physics $\mathrm{Z}$ which had proved damaging to Democritean atomism - above all his objections to the motion of a partless body. How did Epicurus become familiar with Aristotle's arguments? Furley's hypothesis is simply that he had read Physics Z. Labour-saving though this is, there are attractive reasons for seeing Diodorus as an intermediary between Aristotle and Epicurus. It is notable that Epicurus joined Diodorus in accepting, as a consequence of his theory of minimal parts, that it is strictly false to say that an indivisible is moving' and correct only to say that it 'has moved'. ${ }^{6} 6$ This is not in itself a clinching piece of evidence. Diodorus and Epicurus may, as Furley with prudent caution observes, ${ }^{67}$ have been indebted to Aristotle quite independently of each other. Even so, such rehabilitation of a negative Aristotelian argument into a positive doctrine is much more characteristic of Diodorus than of Epicurus; and if it could be shown that a second common feature of Diodorus' and Epicurus' theories of minimal parts had a similar origin, that would, I think, come close to confirming Diodorus' credentials as link-man.

Here a neglected piece of evidence can be brought into play. At the end of the De sensu Aristotle comes up with an argument against the existence of an indivisible perceptible magnitude, which, on the more plausible of the two interpretations favoured by the ancient commentators, ${ }^{68}$ runs as follows. If a magnitude can when sufficiently distant from the eye be seen as the smallest visible magnitude, so that from any greater distance it will be altogether invisible, there must similarly also be a largest invisible magnitude, such that if one moved any closer to it it would become visible. Since no magnitude can be neither visible nor invisible, the smallest visible magnitude and the largest invisible magnitude must be separated by an indivisible point. It follows that no magnitude can be perceived as indivisible, for it would then exactly slot into (or strictly, be 
seen to slot into) that indivisible point at the boundary of the visible and the invisible, and would consequently be both visible and invisible, a logical impossibility. Alexander, comm nting on this argument, remarks, 'From this it seems that the argument about partless magnitudes, whether posed by Diodorus or by someone else, was originally posed and employed by Aristotle. But Aristotle, having invented it, made valid use of it, whereas his high-handed opponents borrowed it from him and used it illegitimately.'69 What argument about partless magnitudes does Alexander mean? The context suggests that he is thinking of one which argues from the existence of a perceptible minimum to that of an intrinsically partless magnitude, such as we know Diodorus claimed to be the basic constituent of matter. ${ }^{70}$ This is in fact confirmed by an earlier passage in Alexander's commentary, where, having backed up Aristotle's claim that no magnitude is naturally invisible, he adds, 'But if nothing is in its nature the smallest perceptible or largest imperceptible thing, there would be no proof that something is in its nature the smallest magnitude, as Diodorus thinks he proves.' 7 !

Apparently then the idea of a perceptible minimum, less than convincingly dismissed by Aristotle, ${ }^{72}$ was rescued by Diodorus as providing proof of his doctrine of theoretical minima. How could the existence of an absolute mathematical minimum be proved from the existence of a perceptible minimum? For an answer we must turn to Epicurus. In his Letter to Herodotus, 56-9, Epicurus offers evidence of a Zenonian kind to show that an atom cannot be infinitely divisible, and then illustrates the nature of the 'smallest thing in the atom' by analogy with the remarkable properties of the 'smallest thing in sensation'. Perceptible minima do not themselves contain parts (i.e. visible parts), yet any perceptible extended magnitude is composed of an exact number of such minima, which somehow manage to combine without touching each other either part to part or whole to whole. This model (in which I can detect no flaw) is intended to enable us to imagine the way in which the smallest thinkable magnitude can serve as a unit in any extended magnitude without itself containing parts. It is not made clear that Epicurus intends this analogy as a further proof of the actual existence of theoretical minima, ${ }^{73}$ but that he elsewhere used it to that end is suggested by the fact that Lucretius unambiguously does so. ${ }^{74}$ Here, then, is a second remarkable coincidence between the Epicurean and Diodorean theories.

The question of partless magnitudes was widely debated in the later part of the fourth century, even becoming a bone of contention between the Academy and the Peripatos. ${ }^{75}$ So to seek the precise influences which 
led Epicurus to adopt such a theory may seem like looking for a needle in a haystack. But as one whose chief commitment was to the Democritean tradition, Epicurus must have made it an overriding concern to rescue atomism from the disrepute into which it had faller as a result of criticism by Aristotle and others; and we have Simplicius' testimony that this was precisely the motive that lay behind his theory of minimal parts. ${ }^{76}$ His theory borrowed as props two notions - that of the perceptible minimum and that of 'having moved' without ever 'moving' - which Aristotle had originally set up as mere Aunt Sallies. The very same pair of notions had similarly been adopted by Diodorus, probably the older man and certainly the more audacious of the two. The evidence does not permit me to go further, but there is already a strong prima facie case here for Diodorean influence on Epicurus. This, if correct, would typify the ways in which I believe Diodorus to have influenced Hellenistic philosophy - partly by providing fruitful ideas and methods of argument, and partly by forcing his contemporaries to re-examine their assumptions and to reformulate them in new and paradoxical ways.

Diodorus' theory of minima need have been little more than a convenient peg on which to hang his arguments about motion. There is at any rate no evidence that he held any other physical doctrines. On the other hand, the doxographers regularly treat it as a bona fide theory about the material elements, and there is one indication that his contemporaries understood it in the same way. Chalcidius, in his commentary on the Timaeus, attributes a particulate theory of matter not only to Diodorus ('min<im>orum corpusculorum coacervationem') but also, as tonishingly, to the Stoics ('corporum diversorum usquequaque concretionem'). ${ }^{77}$ Stated baldly, this latter attribution is patently false, for Stoic orthodoxy certainly held matter to be continuous. But later Chalcidius repeats the claim with more circumspection, crediting the theory to 'Diodorus et nonnulli Stoicorum'. ${ }^{8}$ It is not impossible that Chalcidius has misunderstood his source here. ${ }^{79}$ But it looks equally likely that some of the early Stoics really were so far influenced by Diodorus as to incorporate indivisible units of matter into their physical doctrine. Diodorus may well have rested his denial of infinite divisibility partly on his definition of the possible as 'that which either is or will be true': since no finite body will ever in fact be divided into an infinite number of parts, why should such a division be called possible? Chrysippus, although he did not accept Diodorus' definition of the possible (see $\$ 6$ below), was clearly sensitive to this argument, for in defending the principle of infinite divisibility he spoke guardedly of division as 'unending', admitting that it could not actually be 'to' infinity. It is not impossible, then, that Diodorean 
arguments against infinite divisibility were taken seriously in the early Stoa, and that it was left for Chrysippus to adjudicate the issue. ${ }^{\mathbf{8 0}}$

Another oddity which deserves comment is the attribution to Strato of Lampsacus, Theophrastus' successor as head of the Peripatetic school, of a theory of temporal atomism, presented by Sextus as an attempted solution to the problem of motion. ${ }^{81}$ Wehrli, observing that Strato probably knew Diodorus in Alexandria when serving as tutor to Ptolemy Philadelphus, takes temporal atomism to be his countermove to Diodorus' arguments against motion. ${ }^{82}$ The trouble with this is that Strato is not at all likely to have been a temporal atomist. There is in fact excellent evidence that he upheld the continuity of time. ${ }^{83}$ Until we can establish the true nature of the doctrine misleadingly reported by Sextus, no conclusions about Diodorean influence can be safely ventured.

What led me to this digression about minima was Diodorus' use of them in support of his theory of motion. It should be clear to anyone reading the relevant chapters of Sextus that Diodorus' motion arguments were widely debated and were looked back to by the Sceptics as a fountainhead of controversy on the subject. That is not to say that they were uncritically accepted. Indeed, Sextus has little patience for Diodorus' third and fourth arguments. The third simply runs like this: 'What moves is instantly [or 'at an instant'?] in a place; but what is in a place does not move; therefore what moves does not move.84 The second clause, inadequate as it stands, looks as if it will only become plausible if elaborated into a replica of Zeno's arrow paradox or of Diodorus' first argument. If he had independent considerations to advance in this case, we know nothing of them. The fourth argument will be more appropriately examined under the next heading.

$\S 5$. The Sorites, the Elusive Argument, and the Veiled Argument.

The debate about motion was held to apply equally to all forms of change, and in consequence it is closely linked with a further argument which loomed large in Academic attacks on the Stoics - the Sorites, or Heap Argument. This does not, as has often been maintained, date back to Zeno of Elea, ${ }^{85}$ but is reliably attributed to Diodorus' forerunner Eubulides. ${ }^{86}$ The basic form is this: if fifty grains make a heap, forty-nine grains make a heap; if forty-nine grains make a heap, forty-eight grains make a heap; and so on, until we arrive at the absurd conclusion that two grains make a heap. An opponent may deny this conclusion, but if asked at what point it ceased to be a heap he will be baffled. Another version was the Bald Argument, which apparently asks how many hairs a man can have and still be bald. ${ }^{8} 7$ 
The paradox is at first sight trivial, since we can cheerfully admit that the word 'heap' does not admit of scientific exactness. No scientific or philosophical language will be the poorer without it. It is only when we examine the Sorites' possible range of application that the threat posed turns out to be serious. Take such philosophically indispensable terms as 'irrational' and 'rational'. In growing up a child passes from the one state to the other. Since the two terms are related as contradictories, there can be no intermediate period in which the child is neither rational nor irrational, and none at which he is both rational and irrational. It seems to follow that the transition from the one state to the other is instantaneous. But it is simply not part of our notion of rationality that it can be acquired at an instant, or even within an hour, or a day. What is philosophy to do with predicates which have this sort of vagueness built into them? Frege took the existence of such terms to mark a defect of ordinary language - one of which any fully scientific language would have to free itself. But why? The law, for its own convenience, dates the transition from childhood to adulthood to an instant (midnight on a person's eighteenth birthday), yet this can hardly be thought to provide a scientifically more satisfactory description of growing up than is available from our everyday vague use of the terms 'child' and 'adult'. Nor, in general, are we inclined to think that any distinction is invalidated by the discovery of borderline cases. Rather than adjust our language in order to circumvent the Sorites, we ought to regard any semantic or logical theory as incomplete if it cannot cope with such cases. 88

There is no doubt that the Sorites played a large part in Academic attacks on the Stoics. The best documented examples of this come from Carneades, who ridiculed Stoic theology with a long series of Sorites arguments. A typical example is: "If Zeus is a god, Posidon is a god; if Posidon is a god, Achelous is a god; if Achelous is a god, the Nile is a god; if the Nile is a god, all rivers are gods; if all rivers are gods, streams are gods; if streams are gods, torrents are gods. But torrents 89 are not gods. Therefore Zeus is not a god. But if there were gods, Zeus would be a god. Therefore there are no gods. ${ }^{90}$ If Carneades managed to cause the Stoics embarrassment with such applications of the Sorites, it was because they tended to identify their god with the all-pervading pneuma, and were therefore reluctant to deny all divine status to the cosmic masses, such as sea and air, into which the pneuma diversified itself. 91

But it is also clear that Carneades and his followers were prepared to use the Sorites much more widely than this, as a principal weapon of scepticism against any alleged natural distinction. Cicero in the Academica draws the following lesson: "The nature of the universe has permitted us 
no knowledge of limits such as would enable us to determine, in any case, how far to go. Nor is it so just with a heap of corn, from which the name (Sorites) is derived; but there is no matter whatever concerning which, if questioned by gradual progression, we know how much must be added or subtracted before we can give a definite answer - rich or poor, famous or unknown, many or few, large or small, long or short, broad or narrow. ${ }^{92}$

Having started with Carneades, I shall now try to trace the history of the Sorites back to Diodorus. Before Carneades, Chrysippus had already taken the problem very seriously. He wrote two works on the subject, one

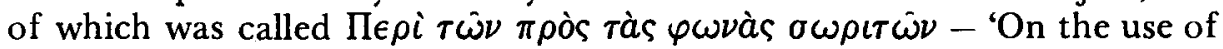
Sorites arguments against words'.93 The title suggests that the Sorites was already being used by the Academics to question the validity of Stoic terminology by exposing the lack of adequate definitions. How did Chrysippus respond? We are told that in his view the correct procedure

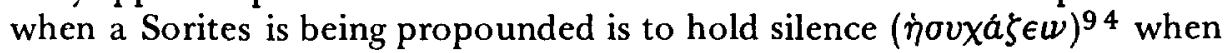
the borderline cases crop up. Perhaps, to be charitable, this was intended less as a logical solution than as a procedural recommendation. Nevertheless, it was eagerly seized on by his Sceptic opponents, and for obvious reasons: what Chrysippus was recommending here was tantamount to a suspension of judgement, a peculiarly Sceptic escape route which, as they readily pointed out, ${ }^{95}$ should be barred to a self-professed dogmatist like Chrysippus.

This still leaves the question, how did Chrysippus view the logical validity of the Sorites? Now there are certain recorded arguments of Chrysippus where he himself uses the Sorites form for the bona fide defence of paradoxical Stoic tenets. What characterises his usage of it is that he expresses each step, not as Carneades did as an implication, "If $\mathbf{S}_{1}$ is $P$ then $S_{2}$ is $P$ ', but as a negated conjunction, 'not both $\left(S_{1}\right.$ is $P$ and $S_{2}$ is not P)'. ${ }^{96}$ This formulation, in Chrysippus' logic, is I believe called a $\pi \omega$ avò $\sigma u \nu \eta \mu \mu \epsilon \dot{\nu} O \nu$ and is used to show that the relationship of the two propositions is something less than one of strict entailment, and hence that error is not ruled out; the connexion is one of plausibility rather than of necessity. ${ }^{97}$ Here I think we can detect Chrysippus' logical analysis of any false Sorites. If the initial premiss was true but the conclusion is false, the error must be located in one specific intermediate step; therefore each step must be formulated in such a way as not to commit you to its absolute validity. 98 Possibly a wise man, if such a person existed, would be able to recognise the false step when it came. ${ }^{99}$

Chrysippus' interest in the Sorites testifies that it was already being used by the Academy against the Stoics earlier than the time of Carneades. Indeed, one attack to which we are told Chrysippus had to reply used the Sorites to question the Stoic doctrine of phantasia 
kataleptike. The doctrine that some presentations are 'apprehensive', or self-evidently true, was always among the most vulnerable Stoic tenets, and in this attack it was asked how the wise man, who assents only to apprehensive presentations, will distinguish the last apprehensive presentation from the first non-apprehensive one. ${ }^{100}$ There are reasons for thinking that this attack was the work of Arcesilaus himself. 101 If so, there can be little doubt how the Sorites was passed to the Hellenistic philosophers from its fourth century inventor Eubulides. ${ }^{102}$ The intermediary must be Diodorus, Arcesilaus' model in his own dialectic.

The only text specifically to mention Diodorus' name in connexion with the Sorites ${ }^{103}$ is too vague to settle the issue. But it was certainly, as we shall be seeing, his habit to borrow the puzzles of Eubulides. Moreover, one of Diodorus' attested arguments bears the unmistakeable stamp of the Sorites. This is the fourth of his motion paradoxes, ${ }^{104}$ which I have held over as being more appropriate to this section. It is a curious argument which relies on the principle that any predicate which can belong absolutely can also belong 'by predominance'. If a man is to turn entirely grey, he must first turn 'grey by predominance', that is, he must come to have more than fifty per cent of his hairs grey. So too with the predicate 'moving', Diodorus claims, the concept of absolute motion presupposes that of 'motion by predominance', which is attributed to a body when more than half its constituent particles are moving. This is then shown to lead to absurdity. Let a body consisting of three indivisible particles have two of these moving and one stationary. According to the principle of predominance, the body as a whole is moving. We now add one stationary particle to the body; but this one stationary particle is outweighed by the three already agreed to be moving. Thus the body as a whole, now consisting of four particles, is 'moving'. We add another stationary particle, with the same result. And so on until the body consists of 10,000 particles - when, absurdly, the body as a whole is still 'moving', even though 9,998 of its particles are stationary.

I shall refrain from commenting on the merits of the argument (which even the charitable may regard as one of Diodorus' feebler efforts), and merely point out that it is a kind of Sorites, leading us by a series of gradual additions to pass from the correct to the incorrect application of a predicate. It is frankly hard to believe that 'moving' is the predicate for which the puzzle was originally designed. Colour predicates are more familiarly attributed by predominance, and Diodorus' own example 'grey-haired' would offer a much more impressive sophism. If, for instance, we take a man whose hairs are predominantly black and add grey hairs one by one until they vastly outnumber the 
black, invoking the principle of predominance at every step, he will still, absurdly, be 'black-haired'. Whereas a normal Sorites would justify each step on the common sense ground that a single hair cannot make the difference between 'black-haired' and 'grey-haired', Diodorus' special version does so by an appeal at each stage to the principle of predominance - any grey hair added is outnumbered by, and consequently assimilated to, the (predominantly) black hairs. It seems to have been the regular practice in the Dialectical school to diversify a single argument into a range of variant forms, ${ }^{105}$ and here we can witness Diodorus' subjection of the Sorites to such treatment. If any doubt remains that this is the origin of the puzzle, it is enough to note that in explaining its principle Diodorus cited as parallels not only 'grey-haired' but also 'heap' ( $\sigma \omega \rho o ́ s) .{ }^{106}$ His claim that an 'absolute heap' presupposes the existence of a 'heap by predominance' is bizarre, for it is hard to think of a term less amenable to this distinction. But the very incongruity serves to confirm that Diodorus is here committed to finding variations on the Sorites theme rather than to any new departure.

We have now seen good reason to believe that the Sorites was a weapon in the dialectical armoury which Diodorus bequeathed to Arcesilaus, and that it is through them that it achieved in the third century the philosophical influence which it had to all appearances lacked in the fourth. What is more, I think it is possible to detect the impact of the Sorites on Stoic thought right from the start. One of the most characteristic early Stoic doctrines is that the transition from folly to wisdom is instantaneous, and with it the transition from vice to virtue. Up to that instant you are totally foolish, bad and miserable, and after it you are totally wise, good and happy. Explaining this notorious paradox, the Stoics used the simile of a drowning man: so long as he is under water he is drowning just as effectively whether he be one or fifty feet under; he stops drowning only when he surfaces, and this occurs at an instant. 107

My question is: were the Stoics attracted to this view by their natural perversity, or were they forced into it? Although the instantaneous nature of change had already received some discussion from Plato in the Parmenides and Aristotle in the Physics, 108 there is no sign that it had ever before helped shape any major philosophical doctrine in this way. It is part of my thesis that Diodorus taught the Hellenistic philosophers to face such paradoxes head-on and to incorporate them into their ways of viewing the world. Surely the Sorites was the tool by which he, or Arcesilaus under his influence, helped shape the Stoic concept of progress from folly to wisdom. The question put to the Stoics will have been this: how can there be a valid distinction to be made between vice and virtue, 
or folly and wisdom, unless you can name the instant in the scale of progress at which a man passes from the one to the other? The Stoic solution was to locate this transition not at some point along the scale of progress but right at the top of it, where it could more easily be pinned down to a determinate instant. ${ }^{109}$ The solution is as extreme as if someone were to react to the question, mentioned earlier, of when a child achieves rationality, by redefining rationality as perfection in logical thought, adding that anyone falling short of perfection in this respect must be written off as totally irrational. But anyone demanding a more palatable solution must first find a way to circumvent the Sorites puzzle.

Although I cannot positively prove my suggestion that the Sorites lay behind this Stoic doctrine, I can produce a neglected piece of evidence to show that another paradox from the stable of Eubulides certainly did influence the Stoics' description of this transition from folly to wisdom. Here too Diodorus must be assumed to be the intermediary. There is a curious Stoic doctrine known as the $\delta \iota a \lambda \epsilon \lambda \eta \theta \dot{\omega} s$ oopos, the 'self-eluding wise man'. When a man first achieves wisdom, they said, there is a brief period during which this fact escapes his notice.110 So what? At first sight the doctrine has little point. And yet we are told that the Stoics gave themselves enormous headaches over it, 111 with Chrysippus devoting a whole work to it. ${ }^{12}$ To see why, we must first note that the $\delta\llcorner a \lambda \epsilon \lambda \eta \theta \dot{\omega}$ s $\lambda$ óros was listed by the Stoics, along with the Sorites and others, among the puzzles that especially interested them, 113 and that its authorship,

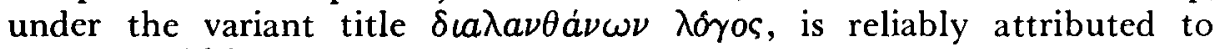
Eubulides. ${ }^{114}$ How it went is not specifically recorded, but the form of it to which the Stoics reacted apparently went roughly like this: 'You say that the wise man is ignorant of nothing, and that nothing eludes him. 115 How, then, can he ever have become wise? For at the instant at which a man becomes wise there is a fact of which he is ignorant, and which eludes him, namely the fact that he is now wise.'116 The Stoic reply was that this is one form of ignorance, or of being eluded, which is compatible with wisdom; and they made some attempt to support this claim with parallels from the processes by which various individual technai are acquired. 117 Plutarch, probably echoing earlier Academic invective, points out the absurdity of this concession, for the Stoics had now stated that the one fact which can elude a wise man is the very one which utterly outclasses all others in moral and intellectual importance. 18

The form which I have suggested for this puzzle is one specifically tailored to an attack on the Stoics, and cannot be quite identical with the original version propounded by Eubulides and his successors. However, its effectiveness against the Stoics rested on their assumption that complete 
self-knowledge is an attainable goal, and I would guess that the original paradox had as its target the Socratic commendation of self-knowledge. If gaining complete self-knowledge consists of mastering a determinate set of facts, facts $1-n$, then the man who has mastered all $n$ facts still falls short of total self-knowledge, because there is now a further fact about himself, fact $n+1$, for him to master, namely the fact that he knows facts $1-n$. And when he has mastered fact $n+1$ there will again be a new fact for him to master....... and so on ad infinitum. Thus complete self-knowledge is unattainable.

In suggesting this formulation for the $\delta \iota a \lambda \epsilon \lambda \eta \theta \dot{\omega} \varsigma \lambda$ ó $\gamma \circ \varsigma$, best translated the 'Elusive Argument', I am inspired by its resemblance to a brilliant section in Gilbert Ryle's The concept of mind headed 'The systematic elusiveness of "I" '.119 Ryle here sets out to explain away the mysterious quality of self-awareness. It is easy enough to write off another person, or even one's own past self, as a being which could be exhaustively described and accounted for; but 'my today's self perpetually slips out of any hold that I try to take'. Ryle attributes this to the impossibility of giving a fully up-to-date account of one's present self: 'My commentary on my performances must always be silent about one performance, namely itself.' The Elusive Argument seems to hinge on this same insight, and concerns, to adapt Ryle's phrase, the systematic elusiveness of self-knowledge.

It may seem that I have been over-confident in attributing such an epistemological motive to the Elusive Argument. But I can now offer some support for this contention by pointing out that another puzzle which similarly passed from Eubulides through Diodorus into Hellenistic philosophy was demonstrably designed to cast doubt on the possibility of

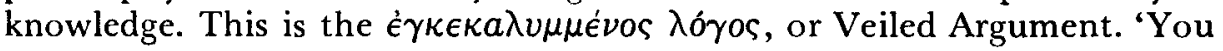
say that it is impossible to know and not know the same thing. Well, you know your father. But if I show you a man with his head veiled you will say that you do not know him. So if it turns out that the man with his head veiled is your father, you will both know and not know your father.' The oddity which this puzzle exploits is one which Quine attempts to describe with a similar example: Cicero is identical with Tully, and yet there may be someone who knows that Cicero denounced Catiline but does not know that Tully denounced Catiline. Quine's reaction is that the presence of a phrase like 'knows that' renders a context 'referentially opaque', and that such contexts do not admit of exact logical analysis. 120 Aristotle, who knew a version of the puzzle, pinned the blame on 'is' in the sentence 'The veiled man is your father' - being the veiled man is only accidentally predicated of him. ${ }^{121}$ Or, as some modern philosophers have 
remarked in similar cases, the 'is' used here is not the 'is' of identity.

It is clear, however, from Hellenistic reactions to this puzzle that it represented not merely a logical enquiry about predication but also a sceptically motivated attack on the whole possibility of knowledge, or at any rate of knowledge through the senses. Knowing something through the senses will be of little value if one can at the same time not know the very thing that one knows. Thus the Academy is said to have used it against the Stoic doctrine of Phantasia kataleptike $;^{12}$ and Chrysippus, as usual, devoted a book to its solution. ${ }^{123}$ But the first Hellenistic reference to it comes in the fragments of Epicurus' Book XXVIII On nature, written in 296/5.124 Here Epicurus outlines his ideas for a new critical method in which theories will be tested by examination of their practical consequences. This method, he goes on to say, will give us a satisfactory solution to riddles like that of the Veiled Father, which he claims to have heard from certain 'sophists'. These 'sophists' were almost certainly Diodorus and his entourage, for the riddle was so closely associated with him that he was sometimes erroneously credited with its invention. ${ }^{125}$ The fact that Epicurus devotes the next two and a half columns to its refutation shows how seriously he took it. There are independent reasons for thinking that at the same time when he wrote this book Epicurus was deeply involved in strengthening his theory of knowledge, in which, as is well known, the validity of sense-evidence is the central tenet. His obvious sensitivity at this time to Diodorus' arguments against knowledge through the senses is an indication that attacks by the Dialectical school may be in part what lay behind his decision to tighten up his epistemology. 126

\section{§6. Possibility and implication.}

Perhaps the most significant single development in Hellenistic philosophy was the recognition of the problem of free will and determinism as a philosophically important one. It was seen that our moral responsibility was threatened if our future actions could be shown to be either causally predetermined or logically necessitated. There are two doctrines here, determinism and fatalism - the one a theory about physical causation, the other about logical consequence - but no Hellenistic philosopher before Carneades recognised the distinction, and both Epicurus and Chrysippus made explicit their reasons for treating the two as a single doctrine. The problem of fatalism had been tackled by Aristotle in chapter 9 of the De interpretatione, which Diodorus had probably read and which in the long term has provoked perhaps more discussion than anything else Aristotle wrote. Yet Cicero's De fato shows plainly that Aristotle's contribution was unknown to the Hellenistic philosophers (indeed, the only mention 
which Aristotle earns there misrepresents him as a determinist), ${ }^{127}$ and that instead Diodorus was seen as the earliest important figure.

Diodorus defined the possible as that which either is or will be true, and

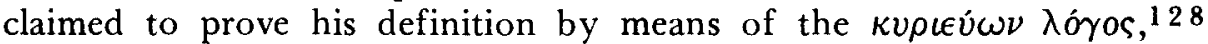
conventionally translated 'Master Argument', although 'Ruling Argument' would be more accurate. According to Epictetus, Diodorus relied on the necessity for at least one of the following premisses to be false: 129

(1) 'Every proposition true about the past is necessary' - a true statement about the past can never become false.

(2) 'An impossible proposition does not follow from a possible one' - a sound rule of modal logic, ${ }^{130}$ already well known to Aristotle.

(3) 'There is something possible which neither is nor will be true' - the view which Diodorus wanted to reject in order to prove his definition.

The following is what I conjecture to be the simplest argument that can be reconstructed out of these three premisses, using basically Stoic language:-

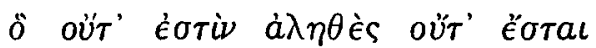

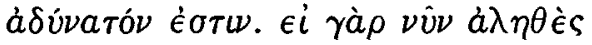

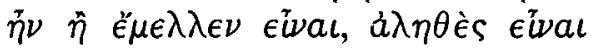
$\dot{\epsilon} \mu \epsilon \dot{\lambda} \lambda \eta \sigma \epsilon \nu$ âv kai $\pi \rho o ́ t \epsilon \rho o \nu$. à $\lambda \lambda$

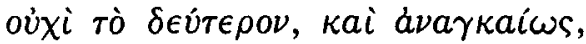

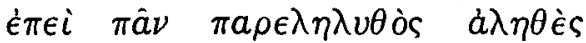

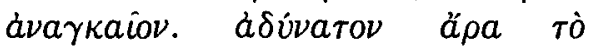

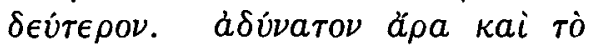

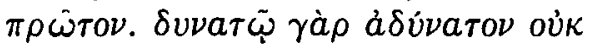

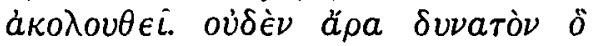

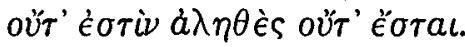

What neither is nor will be true is impossible. For if $(p)$ it were or were going to be true, then (q) it would already in the past have been the case that it would be true. But not-q - and necessarily not-q, since every proposition true about the past is necessary. Therefore it is impossible that-q. Therefore it is impossible that-p, since an impossible proposition does not follow from a possible one. Therefore nothing is possible which neither is nor will be true.

The kernel of the argument, thus interpreted, is that any proposition about the future is impossible if it cannot be true without some false proposition about the past being true. An example will show that this is normally valid. From (a) 'In six years' time she will have a ten year old son' it follows that (b) 'She bore a son four years ago'. If (b) is false, (a) is now impossible; and it is clear that this impossibility arises from (b)'s being false about the past. ${ }^{131}$ We can generalise this lesson by saying that any proposition about the future is impossible if it implies a false 
proposition about the past. But, Diodorus will argue, every false proposition about the future implies a false proposition about the past. For example, in the case of a future ruler, ${ }^{132}$ the false proposition about the future that he will not rule implies the false proposition about the past that it was true ten thousand years ago that he would not rule. Hence this, and every other, false proposition about the future is impossible.

One of my reasons for writing out a skeleton version of the Master Argument is to show that the three premisses listed by Epictetus do not in themselves constitute the whole argument, but are a Stoic's-eye-view of it, concentrating on the three points at which it had actually been disputed by Dialecticians and Stoics. In a way the most important premiss is the one which he omits, the second sentence in my version: 'If it were or were going to be true, then it would already in the past have been the case that it would be true.' Epictetus omits this step because for the Stoics it was uncontroversially valid, and they therefore (see below) saved their attacks for the other premisses. It follows from a principle which the Stoics held sacred, 133 the principle of bivalence, according to which true and false are the only possible truth-values for any proposition, including those about the future. Yet this principle has sometimes been questioned, and as a direct result of fatalist arguments like that of Diodorus. It is still widely held that Aristotle meant to do so in De interpretatione chapter 9; and it is certain that the Epicureans did so, arguing that since it is not yet causally predetermined in nature that Hermarchus will be alive tomorrow, or that he will not be alive tomorrow, neither of these propositions can yet be true. ${ }^{134}$ I suspect that the principle of bivalence was invoked by Diodorus in defence of the second sentence of the Master Argument, and that the Epicurean denial of that principle was a direct reply to him.

It is worth noticing here that the principle of bivalence was certainly used in the $\theta \epsilon \rho i \zeta \omega \nu \lambda o ́ \gamma o \varsigma$, or Reaping Argument, which was a companion piece to the Master Argument, 135 aimed at proving that it is never logically correct to say 'perhaps'.136 It appears self-contradictory to say 'If you will reap, perhaps you will reap and perhaps you will not reap', and equally self-contradictory to say 'If you will not reap, perhaps you will reap and perhaps you will not reap.' But since, by the principle of bivalence, it is necessary that one or the other of these antecedents be true, there is no possible circumstance in which the consequent 'Perhaps you will reap and perhaps you will not reap' will be true.

Epicurus was almost certainly the first philosopher to make a serious study of the free will question, and I have various reasons for thinking that he was first alerted to it only after his move to Athens and at a time when he had already come into contact with Diodorus. ${ }^{137}$ We have 
papyrus fragments of a book in which he defends the concept of free will, and there his arguments are directed against unnamed contemporaries who argue that everything happens out of necessity. 138 This makes it clear that Epicurus' recognition of the free will problem was prompted at least in part by the attacks of contemporary determinists, and it is hard to see who these can be if not the followers of Diodorus.

Diodorus himself was not, I think, a hardline determinist. The object of the Master Argument was to establish definitions of 'possible' and 'necessary', and we know that he kept these two terms carefully distinguished. 139 He did not take the step of identifying the actual, the possible and the necessary. But it is clear from Cicero's De fato that this step was foisted on him, ${ }^{140}$ no doubt by his pupils, and in consequence he came to be associated with the hardline determinist view that all things happen out of necessity.

It remains briefly to describe the reception accorded to Diodorus' modal theory within his own school and the Stoa. His pupil Philo rejected the conclusion of the Master Argument, ${ }^{141}$ and asserted that for a log to be burnt is possible even if it is adrift in the Atlantic and therefore necessarily prevented by circumstances from being burnt. The criterion, he said, is the 'mere suitability of the $i \pi \sigma \kappa \epsilon i \mu \epsilon \nu o \nu$ ', regardless of external circumstances. 142 As a matter of Greek this might mean either the 'mere suitability of the subject term' for receiving the predicate 'is burnt', or the 'mere suitability of the external object' for being burnt. This uncertainty leaves me unclear whether Philo was veering towards a de dicto or a de re notion of modality, and unfortunately the two main sources seem divided on this very point. ${ }^{143}$

On either interpretation, Philo's account looks like the prototype according to which the Stoics formulated their own definition of the possible. They, however, were prompted by their view of the cosmos as a unified whole to modify the definition of the possible to 'that which is capable of being true and is not prevented from being true by external circumstances'.144 This definition presumably renders it impossible for Philo's $\log$ to be burnt. Chrysippus nevertheless saw it as providing an escape route from 'Diodorean' necessity, for it allows many other propositions to be called possible even though they will never become true, simply because nothing positively prevents them from becoming true. Thus he argued against Diodorus that 'It is possible for this jewel to be broken even if it never will be broken'. ${ }^{45}$ The jewel, unlike Philo's log, is not positively prevented by circumstances from being broken. It is not encased in concrete or guarded day and night. Why then will it not be broken? Presumably because there is no causal chain actually leading to its 
being broken. Thus Chrysippus hopes to slip through the determinist's net and to show that there is a valid sense of 'possible' in which it can be applied to at least some things which will not happen: the world is governed by fate, but not by necessity.

To maintain this definition and to escape universal necessity, the Stoics were obliged to put up strong resistance to the Master Argument. There is no evidence of Zeno's reaction to it, but his interest is attested by the story that a Dialectician once offered to teach him seven dialectical variants of the Reaping Argument, and that such was Zeno's eagerness to learn that he paid twice the price asked. ${ }^{146}$ His pupil Cleanthes wrote a work on the Master Argument, ${ }^{147}$ in which he joined Diodorus' follower Panthoides 148 in pinning the blame on the first premiss, 'Every proposition true about the past is necessary'. No details of his argument survive, but he may have contended, as was later maintained by such scholastic philosophers as Occam, that the unalterability of the past belongs only to bona fide events and not to the past truth of propositions about the future. I cannot now cause any of last week's events not to have occurred; but why should I not, by eating an orange, cause it to have been true last week that I would eat an orange? Our instinctive disbelief in the feasibility of bringing about the past may be conditioned by the fact that causal chains always work from past to future, but would be hard to vindicate by any appeal to logical laws. ${ }^{149}$

Chrysippus found himself in a tricky position. On the one hand he felt obliged to ward off universal necessitation by rescuing the third premiss of the Master Argument from Diodorus. On the other hand he could not go along with Cleanthes in rejecting the first premiss, ${ }^{150}$ because he was wedded to a rather crude correspondence theory of truth which led him to attribute the anterior truth of propositions about the future to the pre-existence of causes destined to bring them about: 'futura vera.. .. non possunt esse ea quae causas cur futura sint non habent.'151 Clearly, Chrysippus would say, by eating an orange I cannot be making it have been true last week that I would eat an orange, since that would in turn entail the creation in retrospect of the appropriate antecedent causes. This left him with only the second premiss to attack - that an impossible proposition does not follow from a possible one. To refute this was a tall order, but one which he proceeded to tackle with remarkable ingenuity. 'If Dion is dead, this man is dead' is, he argued, a valid conditional, if the speaker is pointing at the living Dion. Yet taken on their own the antecedent 'Dion is dead' is possible while the consequent 'This man is dead' is impossible. For 'this man' implies the existence of the man denoted, while 'is dead' (understood presumably in the sense 'is no more') 
implies his non-existence. Hence an impossible proposition can validly follow from a possible proposition. ${ }^{152}$ By this manoeuvre Chrysippus probably believed that he had evaded the threat posed by the Master Argument. But we may judge from the remains of Cicero's De fato that the New Academy, far from regarding the matter as closed, continued to hound Chrysippus with Diodorus' determinist arguments. ${ }^{153}$

I have dealt briefly with the influence of Diodorus' modal logic, and shall be even briefer over another logical topic already widely discussed in recent literature, ${ }^{154}$ the criteria for the validity of a conditional proposition. This time it is Philo who seems to have been the pioneer, and here, as in his account of the possible, he proved himself to be among the most modern of ancient logicians, offering a truth-functional analysis of validity corresponding exactly to modern 'material implication'. A conditional is invalid if its antecedent is true and its consequent false; in the other three possible combinations of truth-values it is valid. ${ }^{155}$ How Philo arrived at this notoriously paradoxical position is not recorded, but it is most easily done by interpreting 'If $p$ then $q$ ' as a negated conjunction, 'Not both ( $p$ and not-q)', which is falsified if $p$ is true and $q$ false, and otherwise true. It may have been partly in reaction to this that Chrysippus later distinguished the force of 'if' from that of a negated conjunction, 156 and restricted the former to cases of logical entailment by defining a valid conditional as one in which the negation of the consequent is incompatible with the antecedent. 157

Discounting the unlikely hypothesis 158 that Philo simply failed to notice either the paradoxical consequences of his account (for example, that a false proposition can imply anything at all) or its limited use in scientific reasoning, ${ }^{159}$ we must assume that he was working in a quite different direction, towards some sort of propositional calculus. This may

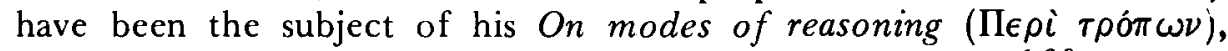
against which Chrysippus was later to write a rejoinder. ${ }^{160}$ It does nevertheless appear from our sources that Philo's definition continued to be held in some esteem by the Stoics, if not as a sufficient condition of validity at any rate as a necessary one. 161

Diodorus himself also took Philo's definition as his starting point, but modified it in such a way as to render the implication universal. A Diodorean valid conditional is one in which it neither was nor is possible for the antecedent to be true and the consequent false'. 162 Noting that Diodorus defined the possible as 'that which either is or will be true', Mates interprets the Diodorean valid conditional as one which 'holds at all times in the Philonian sense'. ${ }^{163}$ If this were correct, it would be hard to see why Diodorus in fact preferred the more cumbersome phraseology reported (in which 'nor is' would be redundant, since 'was not possible' in 
Diodorus' special sense would entail 'is not possible'). More probably, Diodorus chose this formula because he wanted his account of implication to be acceptable even to those whose analysis of possibility differed from his own. Its advantage is precisely this flexibility. If the possibility invoked is logical, the formula yields strict implication; if merely empirical, it offers a correspondingly empirical brand of implication.

Diodorus' concern to convert the Philonian truth-functional conditional into one of universal validity, such as might stand as major premiss in a deductive argument, suggests that he was already working on propositional inference schemata, perhaps the forerunners of the Stoic anapodeiktoi. Indeed, it is clear from his arguments against motion ( $\$ 4$ above) that there was one inference schema of which he was particularly fond:-

If $\mathrm{p}$, then either $\mathrm{q}$ or $\mathrm{r}$.

But neither $q$ nor $r$.

Therefore not-p.

One further topic deserves a mention in this section. Although in defence of the Master Argument Diodorus must have upheld the principle that every proposition is either true or false, it is worth noticing that he also passed on to the Academy arguments which could be used to attack

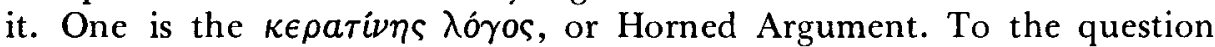
'Have you lost your horns?' neither 'yes' nor 'no' seems the right answer. ${ }^{164}$ The historical interest of this puzzle lies chiefly in the fact that it is, via the scholastic Latin 'argumentum cornutum', the direct ancestor of our phrase 'the horns of a dilemma'. But a second puzzle bequeathed by Eubulides, the $\psi \epsilon v \delta o ́ \mu \epsilon \nu \circ \varsigma$ 入óyos, or Lying Argument, ${ }^{16} 5$ has been vigorously debated from that day to this: if a man says that he is lying, his assertion cannot be true without also being false, or false without also being true. The Academics proclaimed this, along with the Sorites, as their foremost weapon against Stoic logic. ${ }^{166}$

\section{$\S 7$. Meaning.}

Hitherto the question of meaning had centred on the problem of whether words are naturally or only conventionally linked to the objects which they label - the official topic of Plato's Cratylus. Few nowadays would deny that convention, the way in which a word is used within a language, is closely allied to meaning. But another concept whose importance is now recognised is speaker's meaning, which amounts to an intention on the part of the speaker to activate in his hearer a certain belief or action by means of the recognition of that intention. Clearly there are cases of word-meaning where speaker's meaning is absent - a monkey playing with a typewriter might produce words which had a meaning, but not speaker's 
meaning - but it is hard to see how they could have their meaning unless they had in the past been endowed with it by individual speakers using them with this or that intention. Indeed, some recent writers, notably Grice and Schiffer, have maintained that speaker's meaning is logically prior to the meaning of utterances. That was the view put forward by Diodorus too. But he paradoxically overstated it by claiming that there is no meaning but speaker's meaning. 167

In support of his thesis that speaker's meaning is always decisive, Diodorus offered empirical evidence. He allotted to each of his slaves a name which in normal Greek was a conjunction or pronoun. One unfortunate slave was named 'A $\lambda \lambda \grave{a} \mu \eta \dot{\eta} \nu, 168$ 'Nevertheless', another Av̀rov̂, 169 'His', and another pair Mév and $\Delta \dot{\epsilon} .170$ The point, presumably, was that anyone disputing his semantic theory could be asked to witness Diodorus summoning one of his slaves. The fact that the slave responded to this name and no other would furnish formidable proof that to recognise the meaning of a word is nothing more than to recognise the speaker's intention in using it.

One consequence, which Diodorus specifically drew, was that ambiguity is impossible. If someone objected that he was using 'A $\lambda \lambda \grave{a} \mu \dot{\eta} \nu$ ambiguously by saying it sometimes as a conjunction and sometimes to summon his slave, his reply was that since the meaning was wholly determined by the speaker's intention on each occasion of utterance there could only be one meaning at a time, whereas for a word to be ambiguous is for it to have at least two meanings simultaneously. Hence the correct charge against him was not ambiguity but failure to make his intention clear. One can imagine his use of this gambit to throw adversaries off balance when they claimed that one of his puzzles exploited an ambiguity.

Problems of meaning and ambiguity were much discussed in the Hellenistic era, and it is particularly sad that so little from the debate has survived. Epicurus, in On nature Book XXVIII, discusses with his pupil Metrodorus their respective linguistic theories and the ways in which they have revised them in recent years. ${ }^{171}$ Metrodorus, it emerges, had once held a theory of meaning like that of Hermogenes in the Cratylus, that names are purely arbitrary labels, of which one is not to be preferred to another. Now, however, he had abandoned that theory, and his change of heart seems to have resulted in part from his encounters with 'certain people who take words in various ridiculous senses, and indeed in any sense rather than their actual linguistic meanings.' 172 The context leaves no doubt that these opponents are the Dialecticians, and that Metrodorus' abandonment of his old linguistic doctrine had been prompted by his discovery that the Diodorean theory of meaning was uncomfortably like a reductio ad absurdum of his own. 
We learn from the same passage that Epicurus had written a work On ambiguities in response to the Diodorean theory. In the Stoa too, much was written on questions of meaning and ambiguity, and Chrysippus wrote specifically against the theories of Diodorus and his followers Philo and Panthoides. ${ }^{173}$ Where Diodorus had equated the meaning of a word with the speaker's meaning, Chrysippus reacted by identifying it with the sense in which it is, or may be, understood by listeners: 174 since listeners may understand it in two or more different senses, any word can have a plurality of meanings and so be called ambiguous.

\section{§. Conclusion.}

Diodorus' unorthodox method of advertising his semantic theory aptly illustrates the personality which helped him imprint his own mark on Hellenistic philosophy. Such was his reputation that he came, however undeservedly, to outshine Zeno of Elea as the critic of motion and Aristotle as the pioneer of modal logic. Not only the Stoics but even Epicurus, the scorner of dialectic, found themselves obliged to take account of Diodorus' work in these fields. Moreover, those very logical puzzles which were his trademark were inherited and employed to devastating effect by the sceptical Academy; and it was on them, partly in consequence, that the promising new logicians of the Stoa sharpened their teeth.

What does all this amount to? Not a proposal that post-Aristotelian philosophy be renamed post-Diodorean; nor a claim that Diodorus' influence is an explanatory factor which can ultimately be isolated from, and classed above, the influence of others. Rather it is a reminder that those ancient philosophical systems which we rank supreme from our own peculiar historical perspective, further blinkered by the scanty survival of their competitors, by no means dominated the conversation of the young men who thronged the philosophical schools of Athens in the first fifty years of the Hellenistic era. In that age, as in most others, philosophical fashions were dictated by living teachers whose lectures could be attended, whose debates could be personally witnessed, and whose techniques provided a ready model for imitation. Of these Diodorus is an outstanding and unjustly neglected example. 


\section{NOTES}

(For details of works cited, see bibliography appended)

1. This article is an expanded version of a paper read to the Cambridge Philological Society on 13th January 1977. I am grateful for the helpful comments received from members who attended that meeting, and to Malcolm Schofield for his criticisms of a later draft.

2. Landmarks include M.Kneale (née Hurst) Mind 1935, and Development of logic 113-76; Lukasiewicz, Erkenntnis 1935; Mates, $P h R$ 1949, and Stoic logic. I have made some effort to trace Diodorus' influence on Epicurus in my articles in CronErc 1973 and Cahiers de philologie 1976; but in this present study I have tried to think the question out again from scratch, and where it differs from my previous accounts it should be taken to supersede them.

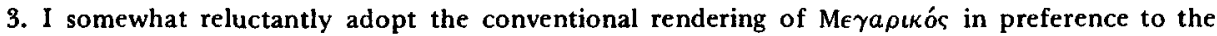

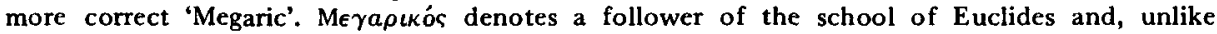
Merapeír, implies no geographical connexion with Megara. Failure to appreciate this distinction has led to many errors (cf. note 12 below).

4. Fr. 33 Döring.

5. I have myself subscribed to the error in previous discussions of Diodorus (note 2 above).

6. D.L. $2.106=$ fr. 31 Döring: oi a $\pi^{\prime}$ a ưrov̂.

7. This interpretation of D.L..'s words goes right back to the entry under 'Euclides' in Suidas ( $=$ fr. 33 Döring); and the Suidas entry under 'Socrates' contains the same confusion. Döring explains 'Megarian' and 'Dialectical' as two successive phases of the school; but, as we shall see, they existed side by side in the late fourth century.

8. D.L. 2.113 = fr. $164 \mathrm{~A}$ Döring; on the reading and grammatical interpretation of the text see also Gigante's important review of Döring, 292-3. I am inclined, however, to take Diphilus of the Bosporus as the former follower (ató carried over from the previous phrase) of Euphantus, not his son. Euphantus, a pupil of Eubulides, came from Chalcidice (frr. 68, 72 Döring) and became tutor to Antigonus Gonatas in Macedon: this makes it less likely that any native of the Bosporus was his son. We may therefore identify both Aristides (otherwise unknown) and Euphantus as early members of the Dialectical school.

9. D.L. 10.8 .

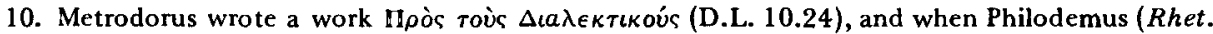

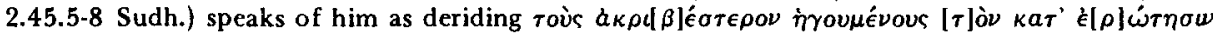

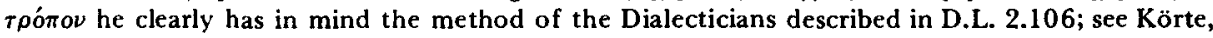
'Metrodori Epicurei fragmenta', 539.

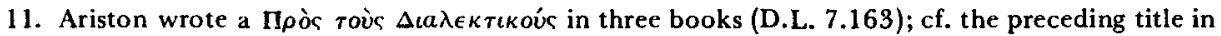

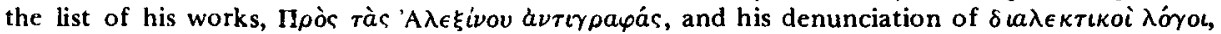
ibid. 161 .

12. Diodorus came from Iasos in Caria. Philo's birthplace is unknown, and it is unfortunate that

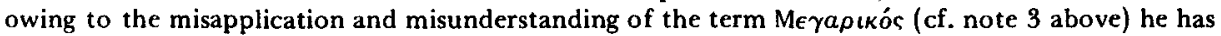
come to be known to historians of logic as Philo of Megara. For their title $\Delta \iota a \lambda \epsilon \kappa \tau \epsilon \kappa o ́ s$ (although the capital letter may not always be appropriate), see frr. 97-8, 101, 104, 106, 109, 112, 132 Döring. 
13. D.L. $1.18-20=$ frr. $35+41$ Döring. Another list of aīé $\sigma \epsilon \iota s$ preserved by Iosippus (Patrologia graeca 106, p.160) from Heraclides the Pythagorean, includes the Megarian while omitting the Dialectical, but the list is so eccentric that no lesson can be drawn (among those listed are the Seven Sages' School and the Theology School!).

14. Frr.31, 45-6 Döring. He was the teacher of Theodorus the Atheist, who was probably born c. 340 B.C.; he was therefore presumably active around 320 B.C.

\section{D.L. $2.106=$ fr.31 Döring.}

16. For Clinomachus as founder of the Dialectical school, see the Suidas entry under 'Socrates' $(=$ fr.34 Döring) and D.L. 1.19 (= fr.35 Döring). He was so little known that D.L. confuses him with Clitomachus of the New Academy, as does at least one other source (fr.40 Döring).

\section{D.L. $2.112=$ fr.32A Döring.}

18. If Clinomachus really was in any sense a pioneer of predicative logic, there is some temptation to date his main period of activity to the early 350 's. This is the probable date of Pliuto's Sophist, in which he took his own first cautious steps in predicative logic and thereby solving certain puzzles which had previously plagued him. Dramatically Plato marks this transition in his thought by the arrival on the scene of the Stranger from Elea, an associate of Parmenides and Zeno. In the opening exchange Socrates' fear that the Stranger may be a practitioner of eristic is quickly dispelled, and in the sequel the Stranger points the way to the solution of some outstanding problems in philosophical logic. One is reminded here of the division which was in fact emerging among the pupils of Plato's friend Euclides, regarded as the current heirs of Parmenides and Zeno (fr.26A Döring). One leading pupil, Eubulides of Miletus, was renowned as a practitioner of sophistical puzzles, and was one of those successors of Euclides on whom the title eristikoi was bestowed by their contemporaries. At the same time Clinomachus was taking some positive steps in the investigation of logic, including the study of predication. A bold interpreter might be tempted to see Clinomachus lurking behind the figure of Plato's Stranger from Elea. The properly cautious might at least admit the possibility that Clinomachus read the Sophist as a criticism of the contemporary Parmenidean tradition and reacted positively by taking up the study of predication. If some cross-fertilisation could be established it would suggest the early 350's as a probable date for Clinomachus' work. Euclides was a friend of Plato - both as early as 399, when he gave Plato and others refuge following the execution of Socrates (fr.4A-B Döring), and still thirty or more years later, when Plato made him the narrator of the Theaetetus. The only explicit evidence for Academic interest in Clinomachus himself is the fact that Speusippus named named a work after him (D.L. $4.4=$ fr.49 Döring).

19. Some of Diodorus' arguments do handle relationships between terms and not between whole propositions - notably the third motion argument ( $\$ 4$ ) and the Veiled Argument ( $\$ 5$ ). My point, however, is that neither he nor anyone whom he influenced is known to have done any work on the logic of such arguments.

\section{See Döring, 73-4.}

21. A probably contemporary comic source calls him où the term was not intended to pick out a specific faction. Indeed, in fr.40 Döring the écortkoi are equated with all the schools in Euclides' diadoche: the three éfortikoi named are Euclides, Menedemus and Clinomachus (Clitomachus codd., corr. Gomperz), clearly selected as the founders of the Megarian, Eretrian and Dialectical schools respectively (Menedemus, a pupil of $\mathrm{Stilpo}_{\Delta}$ was conventionally placed in Euclides' diadoche).

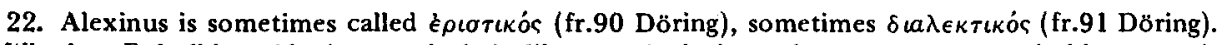
Whether Eubulides, Alexinus and their like attached themselves to any recognisable group is impossible to say. But neither, as far as we know, was a constructive logician. An anecdote about a 


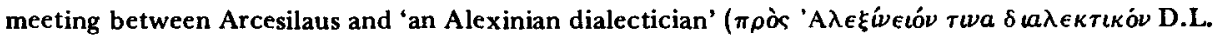
$4.36=$ fr.86 Döring) might be taken to show either that Alexinus belonged to the Dialectical school or that he headed a distinct group of dialecticians. If the latter, the group can hardly have called itself the Eristical school; éplotıkós (cf. Ar. Soph.el.171b 35) is a term of abuse for a debased dialectician. Even so, the title is a contemporary one, since its coining seems to belong

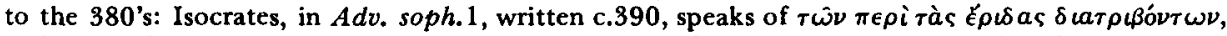

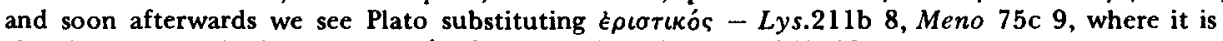
already contrasted with $\delta \iota a \lambda \epsilon \kappa \tau \iota \kappa o ́ s, 80 \mathrm{c} 2,81 \mathrm{~d} 6$, Euthyd. $272 \mathrm{~b} 10$.

23. The chronology can be worked out as follows. The oldest known Dialecticians (excluding Clinomachus) are Euphantus of Olynthus (see note 8 above), noted historian, a pupil of Eubulides, probably born before 348 (Döring,114), and still active in the last decade of the century, when he was tutor to Antigonus Gonatas; Dionysius of Chalcedon (see note 14 above), who first dignified the school with its name; Diodorus Cronus, who was active in Athens and Alexandria c.315-284 (for these dates see $\S 3$ ); and perhaps the Aristides whose pupil Stilpo enticed away (see note 8 above). In the next generation (say 300-270) we continue to hear of the school: Epicurus and Metrodorus attacked it (notes 9 and 10 above), and Epicurus was in turn attacked by one of its members, Heraclides of Bargylia (D.L. 5.94); Zeno of Citium was attacked by Alexinus (frr.92-4 Döring), possibly a member of the school (note 22 above), and is said in an anecdote (D.L. 7.25) to have learned the Reaping Argument from an unnamed Dialectician; Philo the Dialectician, Diodorus' pupil, was also a contemporary of Zeno (D.L. 7.16 = fr.104 Döring), and his mention of Theocritus' Bucolics (fr.138 Döring) suggests that he was still active in the second quarter of the third century; Panthoides the Dialectician (frr.63, 131, 145-6 Döring), who joined in the debate on Diodorus' Master Argument, was active c.280-275, when Lycon, the future Peripate tic scholarch, attended his lectures; and even Diodorus' five daughters, Menexene, Argeia, Theognis, Artemisia, and Pantacleia, became Dialecticians (frr.101-2 Döring). To the same period, or slightly later, may belong the work Against the Dialecticians by Ariston of Chios (note 11 above), a Stoic younger than Zeno. Around the mid third century we hear of a Dialectician named Aristoteles who was involved in the overthrow of Abantidas the tyrant of Sicyon (Plut. Arat. 1028c). Finally, Chrysippus was attacked in a work by a certain Artemidorus the Dialectician (D.L. 9.53); even this, however, need not necessarily be dated later than 250 , when Chrysippus was already 32 years old. Thus there is no firm evidence that the school survived beyond the mid third century. In all the cases cited above 'Dialectician' is apparently used as a proper name to designate a member of a particular school. On the other hand, Stoics since Cleanthes had identified $\delta \iota \lambda \epsilon \kappa \tau \iota \kappa \dot{\eta}$ with their

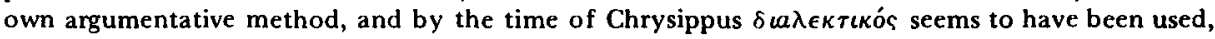
as regularly in Cicero, in the sense 'logician'.

24. This criticism does not extend to Döring. Although his collection and presentation are, on the view proposed in this paper, unsatisfactory as regards the Dialectical school, he shows himself well aware that Stilpo and Diodorus represent distinct factions.

25. It is interesting that Aristotle in Met. $\Theta 1046 \mathrm{~b}$ 29-32, probably written in his second period at Athens, 334-322 B.C., imputes to the Megarians an equation of potentiality and actuality which has something in common with Diodorus' views on possibility ( $\$ 6$ below). In case this should be thought to indicate that Diodorus was himself a Megarian, it should be noted that Alexander in his commentary on the passage (In Met. 570, 25-30 = fr.130B Döring) makes no mention of Diodorus

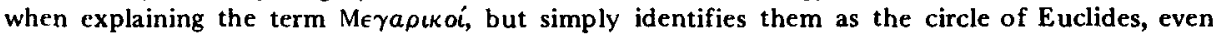
though he was well aware of Diodorus' views on possibility (In An.pr.I 183,34 - 184,10 Wallies = fr.135 Döring).

26. The dialectician's commitment to solving, as well as propounding, puzzles, is rarely dwelt on in the sources, but is apparent, for example, in the story of Diodorus' death ( $\$ 3$ below).

27. Frr.96-8 Döring. Cf. Plato Euthyd.287b; Aristophanes Nub.929, Vesp. 1480, where Koóvovs is

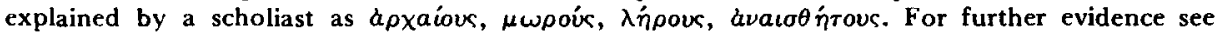
Pfeiffer, Callimachus I 323. On the other hand, Timon's description of Diodorus as $\sigma \kappa o \lambda i o ́ s$ (fr. 107 Döring) lends a little credibility to the suggestion of Hicks, Stoic and Epicurean 320n.: 'The 
surname Cronus .... alludes to his argumentative skill; "crooked-counselling Cronus" is a stock epithet in Homer.' The inheritance of one's teacher's nickname is a curious occurrence, for which I have found no parallels.

28. Frr.103-5 Döring. The bulk of Zeno of Citium's philosophical career was spent in Athens, and in the absence of evidence to the contrary we must assume it to have been there that he studied under Diodorus.

29. For the evidence on this problem, see von Fritz, $R E$ Suppl.10A, $83 \mathrm{ff}$. Zeno's death is reliably dated to 262/1. Our best informant, his pupil Persaeus (D.L. 7.28), says that he came to Athens aged 22 and died at 72: i.e. born 334/3, came to Athens 312/1. Another tradition makes Zeno much older, dying at 98 (D.L. 7.28; Lucian Macrob.19), but this is less trustworthy, especially in view of the ancient biographical tendency to exaggerate longevity. Its most recent defender, Grilli (RFIC 1963), virtually assimilates the two traditions into one by emending Persaeus' figure from 72 to 92 years. But that both traditions existed side by side is, I think, shown by the curious anecdote in D.L. 7.25 that Zeno surreptitiously attended the lectures of Polemo when already a mature philospher. Polemo succeeded Xenocrates as head of the Academy in 314/3: thus while the superior tradition (Persaeus) will have correctly made Polemo Zeno's Academic teacher, the inferior tradition awarded the job to Xenocrates (cf. Timocrates ap. D.L. 7.2, Zeno was Xenocrates' pupil for ten years - an implausibly long time, but the extension of Zeno's longevity will have left an extra 26 years to fill in). The anecdote is thus easily explained as the resort of a baffled biographer trying to reconcile the chronology of the inferior tradition with the superior tradition's report that Zeno studied under Polemo. This leaves a straight choice between the two traditions, and there can be little doubt that Persaeus has the best credentials.

30. See $\$ \S 5$ and 7 below.

31. S.E. $P H 2.245=$ fr. 127 Döring.

32. Cf. J anet Fairweather, Ancient Socicty, 1974, esp. 238.

33. For Herophilus' dates, see Jaeger, 'Diokles v. Karystos', 15, 36ff.; Fraser, Ptolemaic Alexandria II 504 n.58.

34. Callimachus fr. 393 Pfeiffer.

35. Editors tend to take it as pungently satirical in tone: Momus, the personification of fault-finding, is presented as Diodorus' lover, a kindred spirit. I think it an equally possible interpretation that even Momus the fault-finder concedes that Diodorus is wise. 'koia ovv $\hat{\eta} \pi \tau a \iota ;$ '

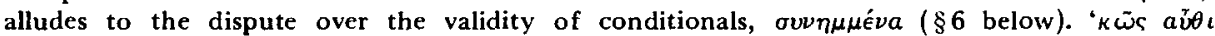

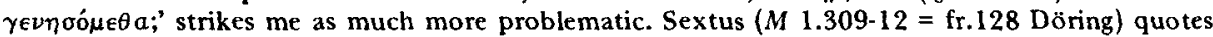
the lines to illustrate the sort of textual exegesis of which philosophers are more capable than grammarians, but then proceeds to make a ghastly mess of it: since Diodorus taught that nothing moves,it followed for him that nothing perishes; 'and if that is so, we live for ever in his opinion and will become hereafter.' Editors quote Sextus' words as sufficient explanation of the lines, but I find them entirely incredible. Diodorus probably did have an argument against the possibility of perishing (cf. S.E. $M 10.347$ = fr.126 Döring), but if so his intention was formally Eleatic and stood on a par with the Eleatic denial of becoming. To express 'we live for ever' by say ing 'we shall become hereafter' is odd coming from anyone, but is sheer self-contradiction in the mouth of an Eleatic. It is slightly more plausible to suppose that Diodorus had an argument against becoming (perhaps that quoted at S.E. $P H 2.243$ and D.L. 9.100), to which the ravens react in consternation by asking 'How shall we become in future?'. But I am not quite clear what the ravens would hope to become in future. Perhaps 'we' means the raven species as a whole, their worry being about future procreation. 
36. For the probability that Callimachus never left North Africa (and therefore could not have met Diodorus in Athens) see Herter, $R E$ Suppl. XIII, 185-6. I am not quite persuaded by the assertions of Wilamowitz (PhU 1906, $124 \mathrm{n.2}$ ), Natorp (RE V 1, 705), and Döring (125) that Diodorus must have still been alive when the poem was written. On the face of it, it is more likely that he was dead; why else would Callimachus use the imperfect $E^{\prime} \gamma \rho a \varphi \in \nu$ in 1.2? But this too is debatable, and does not affect the present issue, since the poem may belong to any year down to Callimachus' death in $\mathbf{2 4 5}$, and since if Diodorus was dead he was clearly not long dead.

37. D.L. 2.111-2 = fr.99 Döring. It has been universally accepted that this incident occurred, if at all, not in Alexandria but in Megara when Ptolemy captured it in 307. The sole ground for this is that 'Stilpo never visited Alexandria'. But. D.L. 2.115, which is cited in support, merely says that Stilpo refused to return there with Ptolemy in 307, not that he never went there even subsequently. If, as seems likely, the source for this refusal was Stilpo's own dialogue Ptolemy (D.L. 2.120), the story no doubt served there to make a moral point about the self-sufficiency of the sage, not to catalogue his travel experience. Moreover, I hope by now to have shown the falsity of the assumption that Diodorus, like Stilpo, was based in Megara. That the incident was located in Alexandria is the only natural interpretation of D.L.'s description of Diodorus as $\pi a \rho a ̀$ П $\tau o \lambda \epsilon \mu a i \omega$ $\tau \bar{\varphi} \sigma \omega \tau \tilde{\eta} \rho \iota \delta \iota \tau \rho i \beta \omega \nu$. The misunderstanding has led most scholars to date Diodorus' death to 307 , at least twenty years too early; and those few who have seen, or suspected, that this is too early (Natorp RE V 1, 705; Furley, Two studies in the Greek atomists, 131; Döring 124-5) have been led to dismiss the whole anecdote, thus depriving themselves of vital evidence for Diodorus' chronology.

38. For a typical recent version, cf. L.Hogben, Mathematics for the million, 17: 'The Tsaritsa commissioned Euler...... to debate with Diderot in public. Diderot was informed that a mathematician had established a proof of the existence of God ...... Before the assembled court Euler accosted him with the following pronouncement, which was uttered with due gravity: "a + $b^{n} / n=x$, donc Dieu existe, répondez!" Algebra was Arabic to Diderot ...... He left the court abruptly amid the titters of the assembly, confined himself to his chambers, demanded a safe conduct, and promptly returned to France.' R.J.Gillings (American Mathematical Monthly, Feb. 1954) traces the elaboration of this story from its original source, D.Thiébault (Mes souvenirs de vingt ans de séiour à Berlin III 141), who had reported Diderot's reaction thus: 'Diderot was willing to show the futility and stupidity of this so-called proof, but felt in spite of himself the embarrassment that one would on discovering their intention of making a game of it, so that he was not disposed to attempt to admonish them for the indignities proposed for him. This adventure made him fearful that there might be others in store for him of a like nature, and so some time afterwards he expressed his desire to return to France.'

39. See note 37 above.

40. Fr.101 Döring; cf. fr.102.

41. Philo also wrote at least two works on spccific areas of logic (fr. 144 Döring) - one

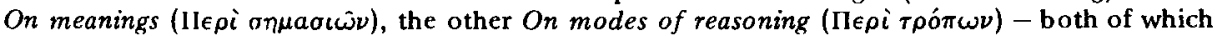
provoked rejoinders from Chrysippus. Now doxographically ( $S V F$ II 152) Chrysippus' views on meaning were seen as opposed to those of Diodorus. Perhaps, then, Diodorus' semantic theory was represented in Philo's On meanings. Panthoides (see note 23 above), probably another pupil of Diodorus, wrote a llepi $\alpha \mu \varphi \iota \beta 0 \lambda_{\iota} \omega \nu$ (fr.146 Döring), which was also attacked by Chrysippus, and may therefore have been a further source, or even vehicle, for Diodorus' semantic theory.

42. Plut. Qu.conv.615a; De san.tu.133b-c; Epictetus Diss.2.19.8.

43. SVF I 49-50.

44. Frede, Die sto ische Logik, 12-26. 
45. Ibid.21; cf. 29.

46. Ibid.22.

47. See $\S \S 5$ and 7 below.

48. S.E. $P H 1.234=$ fr.108 Döring. Cf. frr.106-7, for these and other lines linking Arcesilaus with Diodorus.

49. The association of these puzzles with Arcesilaus is made clear by the classification of titles in

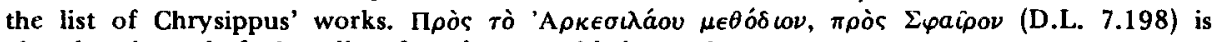
placed at the end of a long list of works on sophistic puzzles.

50. Zeller II 1,266-9.

51. S.E. $M 8.333=$ fr. 143 Döring. This text implies, but does not state explicitly, the argument of Melissus ( 30 B $7(7)$ ).

52. S.E. $M$ 10.37-168.

53. D.L. 9.72.

54. Frr. 123-4, 127-8 Döring.

55. Vlastos's attempt to assimilate it to Zeno's paradox of the arrow does not quite persuade me (Phronesis 1966, 4). Unlike the arrow, which is trapped in an instant of time, Diodorus' would-be mover is trapped in a pocket of space. Fränkel $(A J P h$ 1942. 7, note 20) takes Sextus' remark that

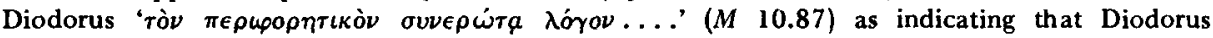
merely adopted an already popular puzzle. But $\sigma v \nu \epsilon \omega \tau \hat{\omega} \nu$ is regularly used for attributing the authorship of an argument (e.g. S.E. $M$ 9.88), and $\pi \in \rho \iota \varphi \rho \rho \eta \tau \iota k o ́ n$ must mean that it is now well known; for $P H 3.71$ is quite explicit in making Diodorus the author (= fr.124 Döring). However, it is likely that the puzzle did eventually infiltrate the lists of Zeno's motion paradoxes, since Epiphanius (Adv.haer.3.11) assigns it to him, and Elias (In Ar. Cat. 109.6 Busse $=29$ A 15 Diels-Kranz) raises to five the number of the paradoxes authoritatively put at four by Aristotle (Phys.Z, 239b9).

56. Fr.126 Döring. Diodorus is also likely to be the author of an argument against becoming, quoted by S.E. (PH 2.243, in a catalogue of sophisms where the two preceding arguments, though

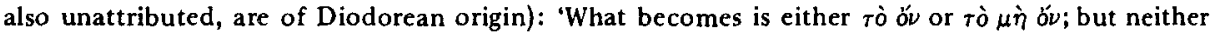
..... etc.' (of course, nothing beyond the formal presentation of this argument is original; in other respects it is that attributed to the 'ancients' by Aristotle, Phys.A, 19l a 23-33). Sextus, with characteristic inconsistency, derides this form of argument in $P H$ yet uses it himself in $M$ (e.g. 7.378-9), as did other Sceptics (D.L. 9.100).

57. S.E. $M 10.87=$ fr. 123 Döring.

58. Ibid.88.

59. If this argument has an Eleatic forerunner, it is Parmenides 28 B 8.29-30 Diels -Kranz, rather than Zeno's arrow.

60. S.E. $M$ 10.105-7. Put in this form the paradox echoes the problem of change formulated by Plato at Parm. $156 \mathrm{c}-\mathrm{d}$, and later treated at length by Aristotle in the Physics (see Owen, 'Tithenai ta phainomena', 97-101). 
61. The principles of mathematics 1,473 : Our knowledge of the external world, 138.

62. S.E. $M$ 10.91-2, $97-101=$ fr.123 Döring.

63. Ar. Phys.Z, 231b21-232al 7, 240b8-24la6; cf. Plato Parm. 138d2-e7; Furley, op.cit.111-4.

64. S.E. $M$ 10.85-6 = fr.123 Döring; more clearly explained at ibid.143 = fr.125 Döring. Cf. Furley, op.cit.,132.

65. Furley, op.cit., 'First study'.

66. Fr.278 Usener. Cf. von Arnim, 'Epikurs Lehre vom Minimum', 14; Mau, Philologus 1955, $107 \mathrm{ff}$.

67. Op.cit., 134.

68. De sensu 449a 20-31. It emerges from Alexander's commentary that some understood the

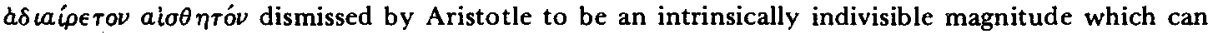
nevertheless somehow be perceived (In De sensu 168.11-171.11), while others (rightly in my view) took it to be an extended magnitude perceived as partless because it is as far away as it can be without actually being imperceptible (ibid.171.12-173.10). It is to the latter interpretation that Alexander appends his remarks about Diodorus (ibid.172.28-173.1).

69. Alexa nder, op.cit., 172.28-173.1 = fr. 119 Döring (part).

70. Frr.116-120 Döring.

71. Alexander, op.cit., 122, 21-3 = fr.119 Döring (part).

72. Aristotle relies on the presumption that if there is a smallest perceptible magnitude there will also be a largest imperceptible magnitude. On the contrary, there cannot be. The two can neither be separated (since then anything in between would be neither perceptible nor imperceptible) nor coincide (since then something could be both perceptible and imperceptible). So we may suppose one, but not the other, to exist. Elsewhere, when discussing change (e.g. Phys.Z, 236b 10-17), Aristotle shows himself well aware of the principle at stake here.

73. Furley (op.cit.,29, 32-3) understands it in this way. But in my view Ep.Hdt. 56-7 proves the existence of a theoretical minimum, while 58-9 demonstrates its nature.

74. Lucretius 1.599-634, 746-52.

75. On the theory of minima in the Academy in relation to the views of Aristotle and Epicurus, sec Krämer, Platonismus und hellenistische Philosophie, 231-362.

76. Epicurus fr. 268 Usener.

77. Chalcidius, In Tim. 203.

78. Ibid. $279=$ fr. 118 Döring.

79. As argued, not entirely convincingly, by van Winden, 'Calcidius on matter', 67-9.

80. Cleanthes set out the orthodox account of the Stoic a $\rho$ Xai in a work entitled Ile $\hat{\imath}^{\tau} \tau \hat{\omega} \nu$ aró $\mu \omega \nu$ ( $S V F$ I 493). Most probably this was an anti-Epicurean work; but it is just possible that atomism was still a live issue within the Stoa too. I know no evidence that the question was settled 
before the time of Chrysippus (SVF II 482-91, esp. 487, which recalls Ar. Phys.Z 231b 1 ff. via Epicurus Ep.Hdt.58; and cf. Todd, Apeiron 1973, 21-9). On the issue of potential versus actual division cf. Furley, op.cit., esp. $148 \mathrm{ff}$.

\section{S.E. $M 155$.}

82. Die Schule des Aristoteles V (ed.1), 63. He appears to have dropped the idea in his second edition.

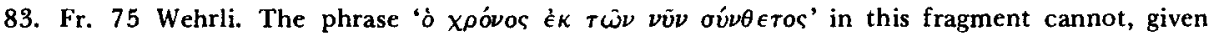
Simplicius' context, be Strato's own doctrine; it is rather an assumption which Strato takes to follow from the view which he opposes, that time is the 'number of motion'. It may be just such a phrase as this that misled Sextus or his source into making Strato a temporal atomist (cf. Gatzemeier, Die Naturphilosophie des Straton von Lampsakos, 127). A further source, Damascius Princ. 389, p.326 Ruelle ( $=$ fr. $82 \mathrm{I}$, Wehrli ed.2) makes time, for Strato, $\sigma \dot{v} \nu \theta \epsilon \tau o \varsigma \ldots . . \dot{\epsilon} \kappa \mu \epsilon \rho \hat{\omega} \nu$ $\mu \grave{\eta} \mu \epsilon \nu \dot{\nu} \nu \tau \omega \nu$. Wehrli (p.65, ed.2) identifies these $\mu \dot{\epsilon} \rho \eta$ with $\tau \grave{a} \nu v \hat{v}$; but Damascius, read in context, makes it quite clear that they are divisible and quite different from tà $v \hat{v} \nu$. (I am grateful for Dr. H.B.Gottschalk's advice on this matter.)

84. S.E. $M 10.112=$ fr.129 Döring (part).

85. That Zeno's paradox of the millet seed is a precursor of the Sorites is a commonplace going back at least to Zeller (II, 1, 265 note 1). I do not dispute Zeno's authorship of the millet paradox, but I do deny that it has anything to do with the Sorites. Zeno (29 A 29 Diels-Kranz) argued against Protagoras that, since a bushel of millet makes a noise when dropped, and since noise varies in direct proportion to the size of the object dropped, a single grain, and even a 10,000th part of a grain, will also make noises proportionate to their sizes. The basis of this argumentation is a principle of proportion, quite unlike the gradual progression employed in the Sorites. Besides, a comparable Sorites would rely on the absurdity of supposing that a 10,000th part of a grain can make a noise; whereas Zeno's contention, according to Aristotle, was that it really does make a noise. I imagine that Zeno's purpose was to demonstrate, against Protagoras, that our reflective beliefs sometimes conflict with the evidence of our senses - a highly effective refutation of Protagoras' doctrine that the truth for anybody is whatever seems to him to be the case, where 'seems' applies indifferently to both sensation and judgement.

86. D.L. $2.108=$ fr.64 Döring. For a comprehensive list of ancient allusions to the Sorites, see Pease (ed.) Cicero, De div. II, 364-6.

87. See Döring, 111-2, on the Sorites and the чалакрóc.

88. Cf. Crispin Wright, 'Language mastery and the sorites paradox'. For a series of papers on the same topic, see Synthese 30 (1975), 265-495.

89. The text has 'But streams are not gods', which is clearly an error.

90. S.E. $M$ 9.182-3. Cf. Cic, $N D 3.52$.

91. Such polytheism is the main target of the arguments recorded by S.E. in $M$ 9. Cf. Couissin, REG 1941. Most of those reported by Cicero in ND 3 attack a different Stoic tendency, that of seeing all the popular deities as attributes of a single god.

92. Cic. Ac. pr. II 92.

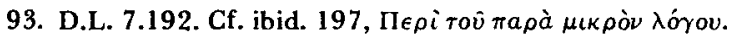


94. Cic. Ac.pr.II 93; S.E. $P H 2.253, M$ 7.416. The Stoics apparently came to use ñovxás $\omega \nu$ as a synonym for $\sigma \omega p$ ítns (D.L. 7.197; Epictetus Diss. 2.18.8; Gellius 1.2.4).

95. S.E. $P H$ 2.253. Cf. Cic. Ac.pr.II 94, probably reporting Carneades.

96. For this formulation in the Sorites itself, see D.L. $7.82=S V F$ II 274; in bona fide Stoic arguments, SVF II 665, 1003, 1005.

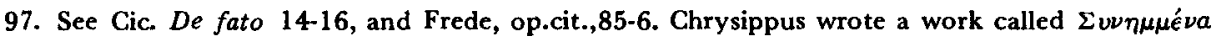

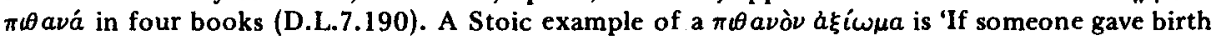
to something she is the mother of that thing', which is false because the hen is not mother of her egg (D.L. 7.75). I take it that if rewritten as a negated conjunction this would not have to be dismissed as false, since the connexion claimed would be one of probability only. That Chrysippus regarded many of his own arguments as plausible but not logically cogent is clear from his frequent use of $\pi \epsilon$ avó $\nu$ in his surviving fragments, even in the titles of several works. Cf. also next note.

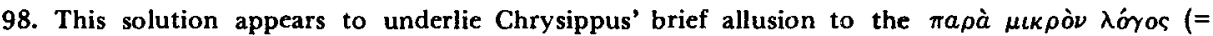

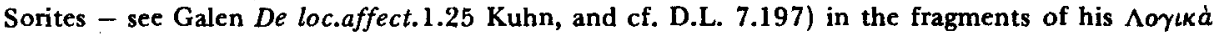

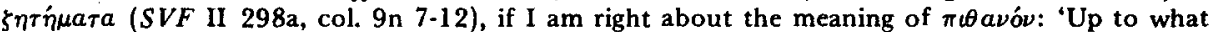

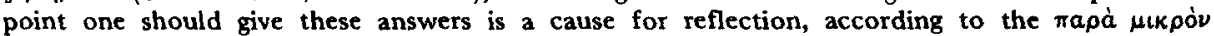

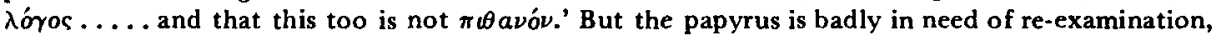
and it would be unwise to pin too much on this text at present.

99. However, in one source (S.E. M 7.416) the technique of ṅouxá Stoic wise man.

100. At Cic. Ac.pr.II 47-9 the progression is through degrees of reliability. If a dream image is plausible, why not probable? If probable, why not barely distinguishable from true? etc. At S.E. $M$ 7.418, however, the qualitative progression is replaced with a quantitative one: the presentation that ' 50 is few' is 'apprehensive' (no doubt the context would explain why - perhaps we are to imagine a general counting his troops), but a Sorites can convert this into the non-apprehensive ' 10,000 is few'.

101. At least, it antedates Chrysippus, if we are to believe S.E. M 7.416 that Chrysippus replied to it. This makes Arcesilaus, from whose attacks Plutarch (Comm.not. 1059 b-c) represents Chrysippus

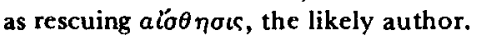

102. I am not at all persuaded by Krämer (op.cit.,75 ff.) that the Sorites belongs within the Platonic tradition, or that the use of it by the New Academy assumes a Platonic structure for the physical world. It is simply a dialectical technique for casting doubt on any qualitative distinction whatsoever.

103. Fr.77 Döring.

104. S.E. $M 10.113-17=$ fr. 129 Döring.

105. For the seven $\delta \iota \lambda \epsilon \kappa \tau \iota k a i$ is éaı of the Reaping Argument, see $\$ 6$ below, and D.L. 7.25. For variant forms of the Horned Argument, see note 164 below. The practice of diversification is also evident in the plurals used in D.L. 7.82 (SVF II 274).

106. S.E. $M 10.114$.

107. SVF III 539 ; cf. 527,530 .

108. Cf. note 60 above. 
109. Some of the reasoning behind this solution is clarified by Seneca, Ep.mor. 118, esp. 12-17. Defending a Stoic account of the Good as 'that which is perfectly in accordance with nature', Seneca anticipates the objection: if most things which accord with nature are morally neutral, why should a mere difference of degree distinguish the Good from these? After all, wine in smaller or larger quantities is still wine. Yes, is the reply, but there are also cases where quantitative change does become qualitative change - for instance, a child's transition from irrationality to rationality in the course of growing up. It is the placing of the final stone that creates an arch: the stone. however small, brings about a major transformation, because its job is not to increase, but to complete. It is in a similar way that what is in accordance with nature can, by quantitative progression, become the Good. (On the Hegelian spirit of this passage, and its connexion with the Sorites, cf. Schmidt, FuF 1960, 112-5.)

110. SVF III 539-41; Plutarch, St.rep.1042f - 1043a; Comm.not.1062b-e.

111. SVF III 539.

112. D.L. $7.198=S V F$ II 15 .

113. D.L. $7.82=S V F$ II 274.

114. Fr.64 Döring.

115. $S V F$ III 548. Nothing eludes ( $\lambda a \nu \theta a ́ v e c$ ) the sage because $\lambda \hat{\eta} \sigma \iota s$ is equivalent to the assumption of a false proposition (Why? Presumably because e.g. not to notice that a black dog has a white hair is to assent to the false proposition 'That dog is entirely black'). Cf. also $S V F$ II 132 .

116. Cf. SVF III 541.

117. SVF III 540.

118. See texts cited in note 110 above.

119. Gilbert Ryle, The concept of mind, 186-9.

120. W.V. Quine, 'Reference and modality'.

121. Ar. Soph.el.179a 39-b 4.

122. S.E. $M$ 7.408-10, where, as the text stands, a different version of the riddle is cited,

123. D.L. 7.198. Cf. ibid. 82; Lucian Vit.auct.22.

124. For text and commentary, see my edition in Cronkrc 1973, esp. 52-3, $71-7$.

125. D.L. $2.111=$ fr. 109 Döring. That it in fact goes back at least to Eubulides is stated by D.L. (2.108) and confirmed by Aristotle's acquaintance with it. A variant version of it, probably of Megarian origin (cf. Euclides' role in the dialogue), was already known to Plato when he wrote the Theaetetus (165c).

126. Cf. art.cit., 13-17, where I argue for this claim.

127. Cic. De fato 39.

128. For the voluminous recent literature on the Master Argument, sec Döring, 133, note 1, to 
which add Purtill, Apeiron 1973. In my opinion the outstanding contribution is still that of Prior, PhQ 1955. It is unfortunate that Schuhl, who later devoted a book to the subject (Le dominateur et les possibles), had not read Prior's article.

129. Epictetus Diss 2.19.1-5 = fr.131 Döring: d̀ kvoє

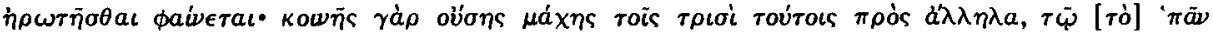

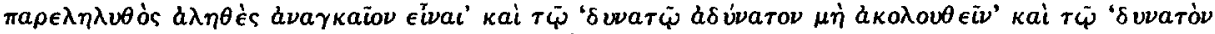

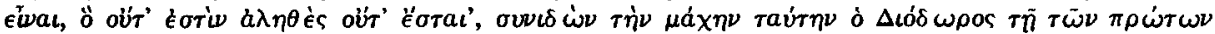
$\delta$ ¿

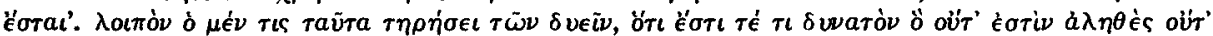

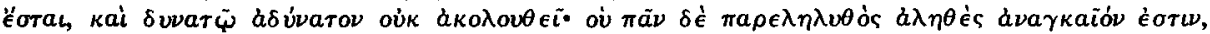

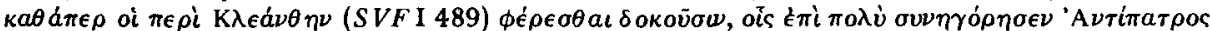

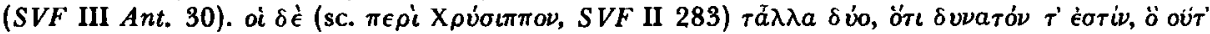

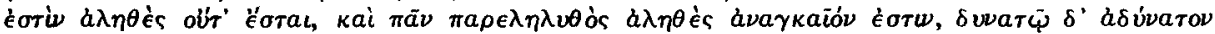

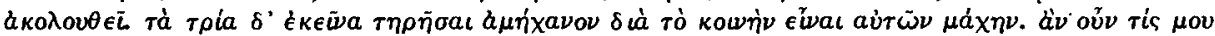

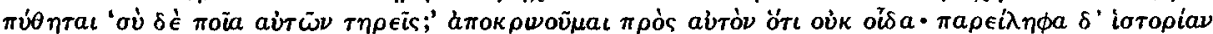

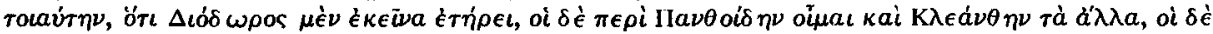
$\pi \epsilon \rho \grave{i}$ Х

130. Of course, there was much dispute in the third century as to precisely what it means for one proposition to 'follow' ( $a \kappa o \lambda o v \theta \epsilon \hat{\nu})$ from another. But the rule remains valid for all the definitions proposed (see below), barring Philo's material implication. This may account for Philo's apparent dissent from the conclusion of the Master Argument.

13l. If (b) were false about the future, (a) need not be impossible. For instance, from $\left(a_{1}\right)$ 'In six years' time she will have a two year old son', it follows that $\left(b_{1}\right)$ 'She will bear a son in four years' time.' Here the falsity of $\left(b_{1}\right)$ would make $\left(a_{1}\right)$ false but not impossible: she will not, as it happens, bear a son in four years' time, but it may still be possible for her to do so. It will be obvious that the brand of possibility under discussion here differs from what is normally now meant by 'logical' possibility. Diodorus is prepared to countenance possibility-at-a-time. This is merely a consequence of the assumption, commonplace in his day, of truth-at-a-time. To suppress this assumption, as docs Mates (Stoic logic 36-41), by treating Diodorus' propositions as propositional functions embodying temporal variables, is to risk distorting his thought.

132. I choose the example of a future ruler because Diodorus' arguments normally borrow their

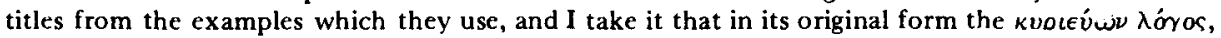
or Ruling Argument, was about somebody destined to rule. In fact Cicero (De fato 13) reports from this very debate the example of Cypselus, of whom it had been prophesied 10,000 years earlier

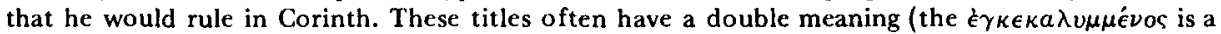
veiled argument about a veiled man, the $\kappa \epsilon \rho a \tau i \omega \eta \varsigma$ is a horned argument, i.e. dilemma, about a

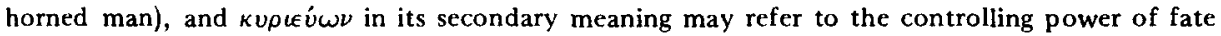
(cf. Schuhl, op.cit., 10).

133. Cic. De fato 20-1, 38 .

134. Ibid.37; Ac.pr.II 97 (= fr. 376 Usener).

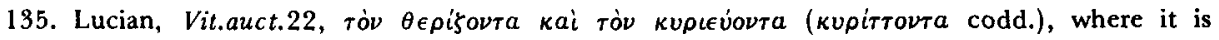
associated with Chrysippus. It is nowhere attributed specifically to Diodorus; but for its association with his Dialectical school, see below.

136. Ammonius, In De int.131, 25-32. Cf. Schuhl, op.cit., 18-19.

137. Briefly, I would state the case as follows. Epicurus probably wrote the Letter to Herodotus around 307/6, the time of his move to Athens (as I argue in CronErc 1976, 45-6, note 73), and in it he still seems quite unaware of the determinist threat: there is no sign of his famous $\pi a \rho \in \gamma^{\prime} \gamma \lambda \iota \sigma \iota$ 
theory, and $a v a ́ \gamma \kappa \eta$ is invoked $(E p . H d t .75,76,77)$ without the hostility which it incurs in the later Letter to Menoeceus (133-4) and in the fragments of his book on free will (ed. Diano, Epicuri ethica, 24-51, = fr.34 Arrighetti, ed.2). This latter may well be Book XXXV of the Meoi yúvews (as I suggest in CronErc 1974,92), datable after 296/5 B.C. when he wrote Book XXVIII.

138. Notably fr.34, 28-30 Arrighetti, where comment on the early atomists' blindness to the free will problem is relegated to a parenthesis within a prolonged attack on contemporary determinists. If the early atomists subsequently became Epicurus' main target on this issue (cf. Ep.Men.134; Diog.Oen. fr.32 Chilton), it is because their brand of atomism could not cope with the problem, not because they were declared determinists. See my discussion of Epicurus' attitude to Democritus in Cahiers de philologie I, 134-5.

139. Fr.138 Döring: the possible is that which either is or will be true; the necessary (correctly interpreted as the 'not-possibly-not') is that which being true will not be false. In other words, necessity belongs only to propositions which can be stated truly both now and at all future times. These must include, above all, eternal and analytic truths, but also certain statements about the past (as in premiss (1) of the Master Argument). By contrast, a proposition is possible if it will express a truth now or at some future time.

140. Cic. De fato 13, 17 (= fr.132A Döring; cf. 132B, 133). A possible but non-necessary proposition is one whose contradictory is possible, and Diodorus' scheme need not abolish this status for all future contingents, since most will be true at one future time and false at another. For instance, that it is a holiday is false now but will be true in the future. However, this distinction can be nullified by the introduction of an exact specification of circumstances: that it is a holiday on 1 st January 1982 in Britain, is and will always be true (if we treat 'is' as untensed: ancient

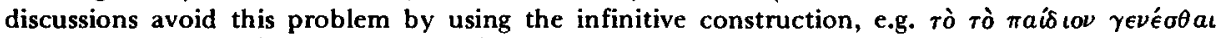

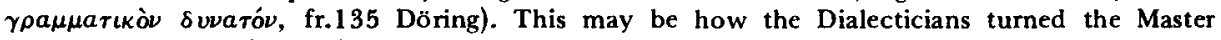
Argument into a defence of universal necessity.

141. See note 130 above.

142. Frr.135-8 Döring.

143. Boethius (fr.138 Döring) takes the de dicto line ('quod natura propria enuntiationis suscipiat veritatem'), while Simplicius (fr.137 Döring) implies a de re interpretation (rò è $\tau \bar{\varphi}$ 'A $\tau \lambda a \nu \tau i k \bar{\varphi}$

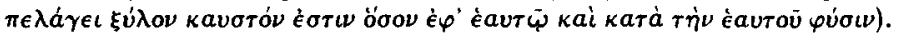

144. For this interpretation, see Frede's excellent discussion (op.cit. 107-117).

145. Cic. De fato 13.

146. D.L. 7.25.

147. Epictetus Diss.2.19.9.

148. Ibid. $1-5$ = fr.131 Döring (for text, see note 129 above). The same solution was later adopted by the Stoic Antipater.

149. Cf. Dummett, $P h R$ 1964. An alternative solution to that of Cleanthes is to argue that a statement of the past truth of a proposition about the future is really a statement not about the past but about the future (cf. Kneale, Development of logic, 119-21). But even if this could be proved (which I doubt), Diodorus can easily substitute an unimpeachable statement about the past, e.g. '(If this man is not going to rule,) any prophet who has predicted that he will rule was bad at his job.' This need not bother Cleanthes, who can maintain that a prophet's success rate is another of those facts about the past which we can still affect by our actions.

150. Cic. De fato 14. 
151. Ibid.26.

152. $S V F$ II 202a. Whatever the fallacy is, it is not, as might appear at first sight, the incorrect use of the token-reflexive 'this' in a proposition. A similarly perplexing example, but without a token-reflexive, is (speaking of someone who lives in Cambridge) 'If he does not live in Cambridge, then he does not live in the town where he lives.' Here the consequent is ambiguous between the possible 'He does not in that hypothetical circumstance live in the town where he lives in actual fact' and the impossible 'He does not live in the same town as himself'. If it is understood in the latter, impossible, sense, then by Chrysippus' own validity criterion (see below) the conditional is invalid, since the contradictory of its consequent is not incompatible with the antecedent. So too in Chrysippus' own example, if the consequent 'This man is dead' is understood as expressing the impossible proposition that the person indicated is simultaneously alive and dead, then its denial will not be incompatible with the antecedent, 'Dion is dead'.

153. Especially De fato 12-13. I accept the hypothesis of Yon in his edition (pp. xl-xlvi) that the De fato derives from Antiochus' Old Academy but that its material is ultimately of Carneadean origin.

154. See especially Kneale (née Hurst) Mind 1935 and Development of logic, 128-38; Mates, Stoic logic, 42-51; Frede, Die sto ische Logik, 80-93.

155. Frr. 141-2 Döring.

156. See above, esp. note 97. It is instructive to note that Chrysippus' ПI

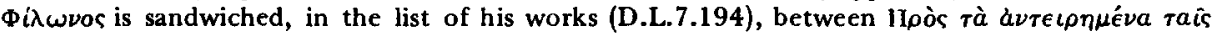

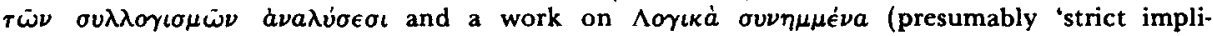

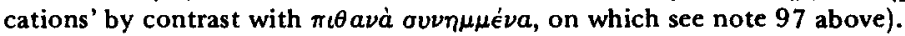

157. See Frede, op.cit., $82 \mathrm{ff}$.

158. As seems to be implied by Hurst, Mind 1935, p. 492.

159. Cf. S.E. $M 8.268,449-51 ; P H 2.115-8$.

160. Fr.144 Döring.

161. Cf. Frede, op.cit., 75-9. It occurs to me that the Stoics' reluctance to abandon material implication altogether might be due in part to their doctrine of cosmic interdependence. It would offer a sense of 'follow' in which every true fact about the world follows from every other true fact. But this is pure surmise.

162. Frr.141-2 Döring.

163. Op.cit., 45.

164. Frr.65, 109 Döring. Alexinus (fr.84 Döring) used the nowadays more familiar question 'Have you stopped beating your father?' See also Döring, 113. For a different version of the Horned Argument, see S.E. PH 2.241, and Becker, Klass.phil. Studien 1957, 54-5.

165. Fr.64 Döring.

166. Cicero Ac.pr.II 95, 147; De div.II 11; Aug. Contra ac.2.5.11. See further, Pease (ed.) Cicero, De div.II, p. 365, and Döring 109-11. For Chrysippus' attempted solutions, see Plut. Comm. 
not. 1059d-f; D.L.7.196-7; SVF II 298a, col. 10n. The puzzle had already occupied Aristotle (Soph.el.180a 39 ff.) and Theophrastus (D.L. 5.49).

167. Fr.111 Döring. There is perhaps a hint at the notion of speaker's meaning in Plato Crat.434e.

168. Frr.112-3 Döring. The idea no doubt came to him from Crat.384d.

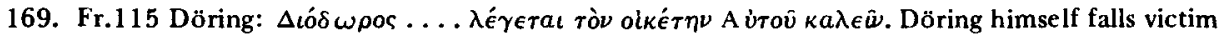
to Diodorus' unconventional usage. He misconstrues aùroũ here as if it were a genuine pronoun, and consequently has to declare the whole sentence unintelligible.

170. Fr.114 Döring. (maĩ $\delta$ as here might equally well refer to 'sons'.)

171. For text and commentary, see my edition in CronErc 1973, esp. 21-3, 41-9, 62-5.

172. Fr.13 col.V 3-12 sup. in my text.

173. See note 41 above.

174. SVF II 152 (= fr.111 Döring). 


\section{BIBLIOGRAPHY}

H. von Arnim, 'Epikurs Lehre vom Minimum', Alm.d.kais.Akad.d.Wiss. (Wien, 1907).

Stoicorum veterum fragmenta (1905-24). Abbr. SVF.

G. Arrighetti, Epicuro, opere ed.2 (1973).

O.Becker, 'Zwei Untersuchungen zur antiken Logik', Klass.-philol.Studien 17 (1957).

P. Couissin, 'Les sorites de Carnéade contre le polythéisme', REG 54 (1941) 43-57.

C. Diano, Epicuri ethica (1946).

H. Diels, W. Kranz, Die Fragmente der Vorsokratiker ed.6 (1952).

K. Döring, Die Megariker (1972).

M. Dummett, 'Bringing about the past', Philosophical Review 73 (1964) 338-59.

J. Fairweather, 'Fiction in the biographies of ancient writers', Ancient Society 5 (1974) 231-75.

H. Fränkel, 'Zeno of Elea's attacks on plurality', AJPh 63 (1942) 1-25, 193-306.

P.M. Fraser, Ptolemaic Alexandria (1972).

M. Frede, Die stoische Logik (1974).

K. von Fritz, 'Megariker', RE Suppl.V (1931) 707-24. 'Zenon (2)', RE Suppl.10A (1972) 83-121.

D.J. Furley, Two studies in the Greek atomists (1967).

M. Gatzemeier, Die Naturphilosophic des Straton von Lampsakos (1970).

M. Gigante, Diogene Laerzio, vite dei filosofi ed.2 1976. Review of Döring, Die Megariker, PP 157 (1974) 291-5.

R.J.Gillings, 'The so-called Euler-Diderot incident', American Mathematical Monthly 61,2 (Feb.1954) 77-80.

H.P. Grice, 'Meaning', Philosophical Review 66 (1957) 377-88; 'Utterer's meaning and intentions', ibid.78 (1969), 147-77.

A. Grilli, 'Zenone e Antigono II', RFIC n.s. 41 (1963) 287-301.

H. Herter, 'Kallimachos', RE Suppl.XIII (1973) 184-266.

R.D. Hicks, Stoic and Epicurean (1910).

L. Hogben, Mathematics for the million (1951).

M. Hurst, 'Implication in the fourth century B.C.', Mind n.s. 44 (1935) 484-95.

W. Jaeger, 'Vergessene Fragmente des Peripatetikers Diokles von Karystos', Abh.d.preuss. Akad.d.Wiss. 1938, phil.-hist.Klasse 3.

W. and M. Kneale, The development of Logic (1962).

A. Körte, 'Metrodori Epicurei fragmenta', Jahrb.für klass.Philol., Suppl.XVII (Leipzig 1890) $531-97$.

H.-J. Krämer, Platonismus und hellenistische Philosophie (1971).

J. Lukasiewicz, 'Zur Geschichte der Aussagenlogik', Erkenntnis 5 (1935) 111-31.

B. Mates, 'Diodorean implication', Philosophical Review 58 (1949) 234-42. Stoic logic ed. 2 (1961).

J. Mau, 'Uber die Zuweisung zweier Epikur-Fragmente', Philologus 99 (1955) 93-111.

P. Natorp, 'Diodoros (42)', $R E$ V 1 (1903)705-7.

G.E.L. Owen, 'Tithenai ta phainomena', in S. Mansion (ed.) Aristote et les problèmes de méthode (1961) 83-103.

A.S. Pease (ed.), Cicero, De divinatione II, Univ. of Illinois studies in lang. and lit. VIII 2 (1923).

R. Pfeiffer, Callimachus (1949-53).

A.N. Prior, 'Diodoran modalities', Philosophical Quarterly 5 (1955) 205-13.

R.L. Purtill, 'The Master Argument', Apeiron 7 (1973) 31-6.

W.V. Quine, 'Reference and modality', in From a logical point of view (1953).

B. Russell, The principles of mathematics (1903). Our knowledge of the external world (1914).

G. Ryle, The concept of mind (Penguin ed., 1963).

S.R. Schiffer, Meaning (1972).

F.(i. Schmidt, 'Ein Frühform der Lchre vom Umschlag Quantität-Qualität bei Seneca', Forschung und Fortschritte' 34 (1960) 112-5. 
P.-M. Schuhl, Le dominateur et les possibles (1960).

D.N. Sedley, 'Epicurus, On nature, Book XXVIII', CronErc 3 (1973) 5-83.

'The structure of Epicurus' On nature', CronErc 4 (1974) 89-92.

'Epicurus and the mathematicians of Cyzicus', CronErc 6 (1976) 23-54.

'Epicurus and his professional rivals', Cahiers de philologie I (1976) 119-59.

D. Thiébault, Mes souvenirs de vingt ans de séjour à Berlin (1804).

R.B. Todd, 'Chrysippus on infinite divisibility', Apeiron 7 (1973) 21-9.

H. Usener, Epicurea (1887).

G. Vlastos, 'A note on Zeno's arrow', Phronesis 11 (1966) 3-18.

F. Wehrli, 'Straton von Lampsakos', Die Schule des Aristoteles V ed.1 (1950), ed.2 (1969).

U. von Wilamowitz-Moellendorff, 'Die Textgeschichte der griechischen Bukoliker', $P h U 18$ (1906).

J.M.C. van Winden, 'Calcidius on matter, his doctrines and sources', Philosophia antiqua 9 (1959).

C. Wright, 'Language mastery and the sorites paradox', in G. Evans and J. MacDowell (eds.), Truth and meaning (1976).

A. Yon (ed.), Ciceron, Traité du destin (1944).

E. Zeller, Die Philosophie der Griechen ed.4 (1899). 